NEW ENGLAND

\title{
WILD FLOWERS
}

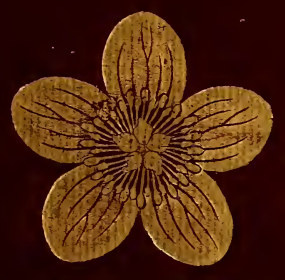





NEW ENGLAND WILD FLOWERS AND THEIR SEASONS 
J6y the same $\mathcal{F}$ utbor

\section{AMONG RHODE ISLAND WILD FLOWERS}

Cloth, 16mo. Four Illustrations

75 CENTS NET 


\section{NEW ENGLAND WILD FLOWERS}

\section{AND THEIR SEASONS}

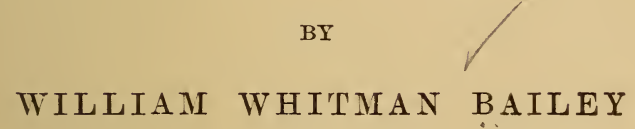

PROFESSOR OF BOTANY, BROWN UNIVERSITY

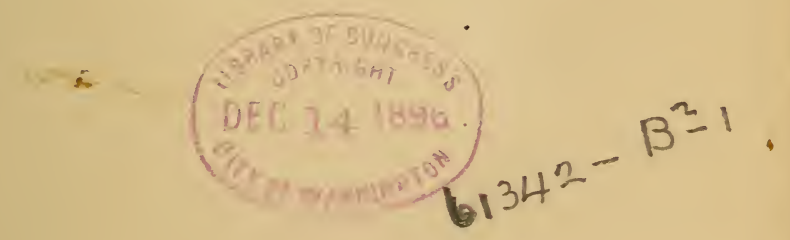

PROVIDENCE, R. I.

PRESTON AND ROUNDS

1897 
Copyright, 1896

BY

PRESTON\& ROUNDS

PRESS OF

E. L. FREEMAN \& SONS, PROVIDENCE, R. I. 
TO THE MEMORY

OF

PROFESSOR ASA GRAY

MY LIFE-LONG FRIEND AND ADVISOR

I DEDICATE

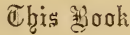





\section{PREFACE}

ThE kindly reception given my "Among Rhode Island Wild Flowers" has led me, perhaps too rashly, to venture once more afield. In enlarging the scope of the work to include New England, my purpose has never been to mention all, or eren a large part, of the flowers of this region. I have collected, rather, the notes of many wanderings by hill and dale, on the sea-shore, or on the mountains, and these stand very much as originally written. It is hoped that they will thus seem fresher and more life-like than if worked up anew.

I have, all things considered, deemed it wise to retain the nomenclature of the last edition of Gray's Manual of the Northern States. All scientific names are relegated to the Index.

William Whitmax Banley.

Browy UNIVERSITY,

Protidence, October, 1896. 



\section{CONTENTS}

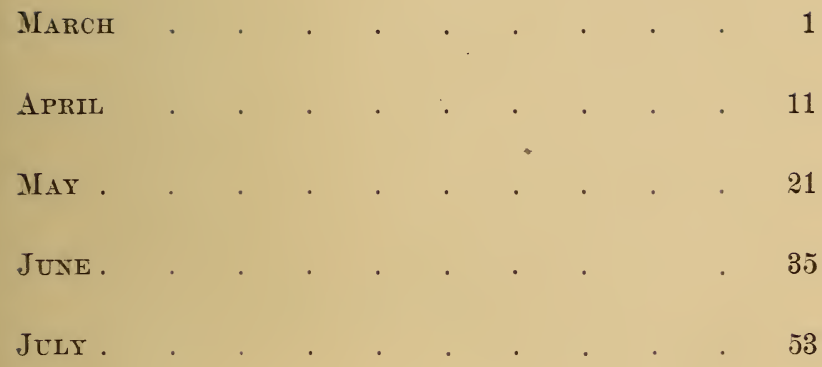

New England Alpines . . . . . . 65

Auglest . . . . . . . . . . 73

Plants of the Sea-Shore . . . . . 85

SEPTEMBER . . . . . . . . . . 93

OCTOBER . . . . . . . . . . 103

Notember . . . . . . . . . . . 113

WINTER . . . . . . . . . 123

INDEX * . . . . . . . 137 

MARCH. 
See, pretty Pussy-Willow,

In ermine mantle clad,

Is strolling by the river

To make the Alders glad,

For all her yellow tresses

Are gleaming now with gold-

The breezes gently toss them

In many a wondrous fold.

These are my vernal darlings-

This ever-wedded pair:

My lad with silken raiment;

His lass with golden hair.

With merry words I greet them;

The blue-birds sing amain,

"The sweet south wind is blowingThe Spring has come again!" 


\section{MARCH.}

There is now a breath of the coming spring. The village poet writes lines upon the anemone and violet; the blue birds have arrived; the robins, fat and saucy, hop once more upon the lawn; the clouds assume the fleecy forms of summer. Moreover, we detect furtive symptoms of house-cleaning, and begin to tremble for our farorite spider-web. New brooms and shining dust pans are in order, and the annual hegira looms in sight.

The brown buds of the elms can barely wait, the impatient leaves are so anxious to expand. The tips of the maples blush with the coming bloom, the lilac buds are green and prominent, and those of the horse-chestnut every day enlarge. These burly fellows wear tarpaulins to keep out wind and rain. It is interesting to open one of the buds, so carefully packed, and to find the tender leaves within. They are hidclen in layers of cotton wool, orer which are imbricated scales wet with a water-proof vamish, very adhesive to the touch. No retail salesman could do up a package so compact and withal so safe. Often, too, a bud is perfumed with a delicate and spicy aroma. It contains 
flowers or leaves, or perhaps both, but as yet incipient.

Better than all indications of the increasing sunshine is the flush upon the grass. It is the merest suspicion of green, but it is a promise of golden buttercups, of dandelions and daisies.

How busy is Nature now beneath the soil, where streamlets trickle down to unseen wells; where the roots are feeling about for generous moisture, and where the subterranean buds and bulbs are growing! Should we put an ear to the ground, like Fine-ear in the fairy tale, we might discern what was coming. The long sleep of the flowers is drawing to a close, and soon each plant must be up and doing.

In these early days one hardly expects any thing to reward him for braving mud and snow, but often he is pleasantly disappointed. Nature has not been idle in the long winter; here is the skunk-cabbage in full perfection. They are curious plants, with hoods projecting from the ground as if they belonged to buried Capuchins. The most eccentric fancy could hardly call their odor pleasant. It haunts one a long time as an agonizing memory. The spathes themselves have a wild sort of beauty. They are prettily blotched with red or yellow, and no one should despise them, for they are enterprising above all plants. It must require great courage to spring up out of half-frozen ground, to look upon snow drifts and heaps of sodden foliage. 
These plants are near relatives of the calla and Jack-in-the-pulpit. The flowers are followed soon by broad, green, very verdant, netveined leaves. Their tufts henceforward become very conspicuous in marshy places, and are only rivalled by the hellebore, which appears about the same time.

On sandy banks even in early March one may detect the tiny whitlow grass, one of the cress or mustard family, an emigrant from Europe. Before the month is over it is in full pod. Another plant to bloom very early is the silver-leaf maple. The blossoms are hardly so pretty as those of the red. Of course chickweed will by this time be found in flower wherever the snow is off the ground. A very hardy plant this, of almost alpine habit.

It is now the festival time of the mosses. They are never again so beautiful. The green of other plants seems tame beside their velvety verdure. We find them carpeting the cliffs and banks of streams, or forming luxurious cushions for the feet of some tree. Among the first plants to appear upon the earth when the dry land emerged from the primeval ocean, they imitate in their fantastic growth all subsequent vegetation. We find among them pine forests, as it were, in the miniature branches of which, were our ears attuned to hear them, we might note many a breezy melody. Some of them assume the forms of diminutive ferns; others are like palms or cycads. They do not disdain even to 
mimic the costumes of men, and imagination sees in them at times a mighty army, gay with lance and pennon, setting forth upon a journey of knightly emprise.

The microscopist may well revel in the exceeding beauty and interest of their fructification, and the lover of nature, in the elegance and variety of their colors.

We may at this season study an incipient geology. One can see in miniature much that has happened throughout the ages; the denudation of surfaces; the filling in of valleys; the formation of caverns; the deposit of deltas; the disintegration of mountains; the laying out of alluvial formations, and even the growth of terraces. On a mere rivulet we have noted all these changes, and have magnified what we saw till we seemed to stand in the presence of the mighty forces which created continents and disposed the course of rivers. He is indeed narrow-minded who refuses to learn a lesson from little things. The melting ice, the effervescent spring-the mere dry lichen on the surface of a rock, may preach most eloquently.

We are treated to sweet music in our early ramble. Like Jessica, we are "never merry" when we hear such, but rather become merlitative. The streams sing to us as they dance over' the pebbles, and the birds warble in tree-tops and hedges as if their wee bodies could no longer contain so great an excess of joy. The 
tree-toads or hylas, too, are just beginning their sweet chorus from the bogs.

The woods are full of insects, gnats, flies, and even mosquitoes. We could almost wish a cold snap would surprise the latter. A great purple butterfly, the Camberwell beauty, or mourning bride, floats in and out amidst the shrubbery like a spirit. Psyche among the Greeks meant the soul as well as a butterfly. Whose soul is it, we wonder, that haunts the New England dells? Perhaps that of some Puritan maiden.

Although there is still snow and ice under the lee of stone-walls and on northern hillsides, we will awake some morning to find the spring at hand. The sap is already coursing through the woody veins of the maple, and its swelling buds are ready to burst forth. The water starwort mantles the silent springs. Wasps bask on sunny windows; even chanticleer has caught the prevailing spirit; his challenge is particularly emphatic.

To us the most bewitching things of all, for they are so replete with promise, are the brown tassels of the alder and the hazel-or the silky catkins of the willow. They seem just ready for the kiss of April, and in a moment they transport us to the days when the sweet south wind is to awaken the anemone.

How much must they lose who dwell in an unvarying season! The fruits and flowers of the tropics could not repay us for the loss of 
spring and antumn. Even winter affords scenes of bewildering beauty that we conld ill spare. Who would not miss from his life the

"Passionate glow of the sweet spring season?"

It is as fresh with us now as ever. Other things change; even friendships fade. We see Will and Harry walking arm in arm in college days, but in five years maybe they will merely touch their hats. Certain books now make us yawnthat were once to the highest degree dramatic. The theatre and the opera notably lose much of the subtle charm which once transmuted tinsel into gold, but nature still holds an unalterable allegiance. 'The first violet or' anemone causes us to clap our hands as it did a score of years ago. When we see the hepatica, blue-eyed, coy, peeping from the rocks of some sunny hillside, we burst into extempore song.

There are comparatively few people who know that the alder, hazel, Mayflower, and many other plants show their flower-buds in the autumn. They are formed the prerious summer.

The signs we note of the advancing spring are hard to put into words. There is, in the first place, a smell of fresh earth that the woodlover learns to know. It stirs some remote ancestral instinct, perhaps transmitted from the time when our forefathers roamed the forest. Then there are the distinctly marked colors, rivid green or bright red, of the twigs of various shrubs and trees, full to orerflowing with vigor- 
ous life. Certain crustaceous lichens, begin to assume their lovely flesh colors, while mosses invite us by their treacherous cushions. It will be many weeks yet ere it will be safe to trust these forest seats. Those who know where to find them will perceive the pure white or rosy pink buds of the trailing-arbutus-It never loses its charm.

We have alluded to tassels, or as the botanist calls them, aments. Very many of our shrubs and forest trees blossom in this way. They are especially noticeable in spring-most of such plants being wind-fertilized and consequently having the flowers precede the foliage. We have, first of all, the alders, the long tassels of which hang orer the banks of streams. At the same time many of the willows protrucle their silky aments, which are popularly known as "pussies." No particular species perhaps can arrogate that title, though some are more silky than others.

The willows are always a difficult study. The flowers precede the leares, which must be collected later. One must also possess the fruit, and as the plants have two kinds of flowers, on separate trees, the complementary kinds must be secured. Then, when the leaves are obtained, one must be certain that they pertain to the flowering specimens before collected. The willows and alders, beloved of Thoreau, are the true harbingers of spring. The hazels tassel out in March also. The staminate aments in these 
are absurdly like worms. If one looks a little closely he will detect on the same shrub the pretty crimson stigmas of the female flowers. The hazel is a charming bush at any season, and its nut, encased in a sort of frilled enrelope, is a theme for an artist. The beaked hazel is equally pretty.

Nature especially delights in tassels. We find them in sweet-fern, the birches, poplars, nuttrees, iron-wood, etc. While most common in early spring, they are seen often, as in chestnuts, in midsummer. In these they form great fountains of cream-colored flowers. 
APRIL. 


\section{HEPATICA.}

Thou blossom blue, with laughing eye,

I cannot tell the reason why

Thou art so dear, except for joy

Thou broughtest to me when a boy.

Ere snows had left the woodland ways

On sunny morns of April days,

I found thee smiling as in glee,

And peeping through the leares at me.

The alder bushes barely show

Their golden tassels o'er the snow;

And pussy willow's silken cap

Proclaims her yet unbroken nap.

But thou, bright flower, brim full of mirth Art here to welcome April's birth-

A sign to us that not in vain

Has been the winter's snow and rain. 


\section{APRIL.}

The real Spring performance begins with us in April. A green carpet of grass is spread upon the stage, and secured by the golden tacks of dandelions. The marsh-marigolds kindle their glowing foot-lights-and, hark! the antiphonal chorus from the swamp, where the hylas are loudly rejoicing. The guttural note of a bull-frog affords a fitting bass to the high treble of his kindred. Can those uncurling fern-fronds be indeed, as they are called, the "fiddle-heads" of this merry orchestra? How pleasant is the overture to the coming concert of the birds, of whom now some solitary prima donna flings forth her glorious melody.

Nature has in the long winter elaborated a new stock of colors with which to adorn her theatre, for note how bright is the blue upon the riolets, and how brilliant the green of the hellebore. Beneath the faded mantle which Autumn cast upon the earth we now find the Mayflower in all its beauty. Prose will not answer for its description, nor has poetry done it entire justice. While the meadows are yet brown and the trees are leafless, while perhaps even yet the snow may linger behind some se- 
cluded wall, it sweetens the spring air with its delicate breath. It is the only flower which rich and poor alike vie with each other in obtaining. Near our cities it is rapidly disappearing. One who has seen it only in the bunches sold in cities obtains no idea of its beauty. Its entire habit is changed by this artificial massing. In farorable places it grows in long, luxuriant trails, half concealed by fallen leaves, and with the rosy blossoms clustered at intervals. It loses the artless simplicity which is its chief charm when cut and trimmed into shape. It is one of those plants, too, whose very nature seems to crave a wild neglect. Its normal enrironment is ever romantic. Coming so early, intrinsically so charming, it is little wonder that it is the chosen and belored flower of New England--first known by our forefathers, and hence dearly cherished.

As fair a flower but not so sweet is the blueeyed, frolicking hepatica or liver-wort, which plays bo-peep from behind the mossy rocks. Its old leaves, which have their entire and rounded lobes, are evergreen and glossy. The flowers rather precede the new leares, which come up covered with silky down. Near the calyx which may be blue, pink, or white, is an involucre of three bracts, often itself mistaken for the calyx. There are fer flowers that have so much expression, such an intense air of enjoyment and life. They gladden the rery heart of the stroller-and one, who has in youth learned to love 
them, feels homeless in a region where they are not. The first-found hepatica is an event, and the last one does not cloy.

The saxifrage whose name denotes it a "rockbreaker," merits its title from its farorite position in the chinks of cliffs, which its tender stems persuade, rather than rend asunder. Often rocky hillsides are whitened with its small white flowers. These are in cymes, borne on a naked and rather hairy stem, arising from a rosette of spatulate leaves.

The red-maple is now flinging its ruddy censers-lhow sweet they are!-the flowers of the shad-bush are flying like white butterflies among its silvery leaves, and the wood anemone rentures to unfold its fragile beauty. This little plant is common to both worlds--and is lored in both. In some parts of the country it is replaced, at least in a degree, by the anemonella, or rue-anemone. This is a native-and is eren more charming. Near these we often find the perfoliate bell-wort. By banks of streams grow the pure white flowers of the blood-root and later the yellow adder's-tongue or dogs-tooth violet.

The little five-finger or cinque-foil, called Potentilla by the learned, owing to some mystic virtue it was at one time supposed to possess, with its first cousin the strawberry, now bespangle the meadows with yellow and white. Our most common potentilla is the Canadian, but the silver leaf springs up along roadsides 
and in dry fields, while in western Massachusetts and Connecticut, the shrubby species is a terrible nuisance.

In some parts of New England the bluets, innocents, Quaker-ladies, or stars of Bethlehemit bears all these names and some four botanical ones besides-is a representative flower. It springs up in detached groups in grassy meadows -at first sparsely, but after a while the groups combine to whiten the fields as with snow. Nothing can be prettier than these delicate plants. They have, too, a long period of blooming. They are of two forms,-dimorphus-one little group showing flowers of one form, and the next quite different, an arrangement to insure cross-fertilization. The corollas are salverform, bluish, or white and with a yellowish eye. In one group the stamens will project from the tube and the style will be short; in another the style is exserted and the stamens low down in the tube. Many of the madder family to which these plants belong,-show this advantageous difference of form.

We often think the columbine is the most graceful of all our flowers. Loving to nestle in the chinks of rocks and weather-beaten cliffs, its delicate foliage flutters in every breeze, while its scarlet blossoms hang out like jeweled pendants. Much loved of bees and boys; both have discovered the honey-laden spurs.

The star-anemone is found in shady woods, and is a member of the primrose family. It is 
curious to note in it the numerical plan of seven. Emerson tells us that "Nature lores the number five." She is about equally fond of the number three, but seven, though no doubt lucky, is rare. The word prim-rose, we learn, is old English for prime-rose, the first rose, a pretty derivation. Hereabouts we have no true native primroses, our so-called cowslip being the marsh-marigold of Europe. How glorious are its yellow stars in "swamps and woodlands gray!"

There can now be found regular camp meetings of Jack-in-the-pulpit. The earnest preachers are drawn upright in manly energy, but in dignified silence. The attuned ear only can catch the words of the sermon, but it is well worth hearing. Love of God and man enters largely into it. The erring is given a chance to repent; the sinner to return to righteousness.

An interesting order of plants, to which belong the mountain laurel and azaleas of June, is now represented by many vase-formed flowers, quite as pretty in their way as their gorgeous relatives. It is the heath family which gives us in April the white flowers of the leather leaf. To this family belongs the leather leaf with its urn-shaped, white corollas, hung beneath the branches, which bear erergreen leaves, scurfy underneath. The shrubs grow abundantly in bogs - especially northward. Still farther north the even prettier rosy andromeda comes in. In this same family the various 
species of huckle-berry and blue-berry. The variety of form exhibited in these little vases, and their delicate shades of color, ranging from pure white to yellow ochre, and in one, andromeda, to pink, are truly wonderful.

Another pretty plant, and this, too, is of the heath family, is the creeping snow-berry, a trailing evergreen, aromatic, and with small flowers on nodding stems. Its berry is quite large, globular, white, and often spotted like some birds' eggs.

The fair Rhodora belongs rather to May. It has an azalea-like appearance, and the magenta flowers precede the leares. It is a shy plant, and loves best the depths of some secluded swamp. Emerson has celebrated it in one of the sweetest of his poems.

Among the shrubs one is now quite conspicuous in the woods. It is the spice bush, or ferer bush. The small yellow blossoms are grouped in clusters in the axils of last year's leaves. The foliage of this season is developed later. The stamens are extremely pretty microscopic objects, their anthers opening by uplifted valves. The whole plant is spicy to the taste and smell. In autumn it bears brilliant red berries. It, with the sassafras, belongs to the true laurel family, which our mountain laurel does not. If one wishes to see the leaves of true laurel or bay, used to crown heroes, he can find them often in fig boxes.

All Nature now seems ready for some sudden 
transformation. Now the scene is cold and cheerless, and the light turned off; suddenly there is a blaze of sunshine illuminating the garden of the fairies. 

MAY. 


\section{JACK.}

I found a camp meeting of teachers, Most wonderful ever was seen ; Such quaint and prim little preachers, In pulpit of purple and green.

I knew not the words they were saying ; The sermon did not understand, But saw all the flowers a-praying And hid my own face in my hand. 


\section{MAY.}

"Behold me ! I am May!"

The May sunshine is now bright in the meadows. The pretty innocents that in April roamed at will have gathered in groups as if talking over the situation. If they were not innocents one might infer that they were politicians in heated discussion, but with such pretty faces they cannot be office-seekers, though lobbyists maybe. Rather may they be compared to young girls planning a glad surprise. Very demure and sweet are they in their lavender bonnets. Some are so shy as to turn away their heads.

Violets are now everywhere. The large birdfoot species troop together in blue files, as if Nature had unstrung her necklace of amethyst and scattered the beads by the wayside. Hawthorne says in his notes:

"A gush of violets along a wood path."

This particular species is not found far from the coast. It loves sandy soil, and makes glad the waste. The true white violets, on the contrary, prefer damp situations. These have their snowy petals streaked with dark lines, as "blue veins meander a liberal hand." These streaks of 
color, as long ago shown by Sprengel, serve as "guiding lines," leading insects to the nectar.

The small yellow violet, common in some parts of New England, is rare or unknown in others. It is stemless, and after the flowers pass away the large round leaves, pressed close to the ground, are conspicuous all summer. The plant is one of those that associates itself in memory with deep, secluded dells, shady ravines and hidden springs. We mention it with bated breath. It has had no less a singer than Bryant.

"Thy parent sun, who bade thee view

Pale skies and chilling moisture sip,

Has bathed thee in his own bright hue,

And streaked with jet thy glowing lip."

The downy yellow violet, and its smooth variety, is also local, but usually abundant enough where it occurs. We are most familiar with it along the banks of runs and rivulets. It is found, too, in rocky ravines, where the cool mosses cushion the rocks and fern feathers droop orer the babbling stream. In such places, also, will be found the showy orchis, with its ineffable perfume, and the grotesque flowers of wild ginger. Here the exquisite mountain fringe trails over the rocks, and one lights upon that gem, the yellow lady-slipper.

Anemones, shy in April, now stud the copses everywhere with stars. The rue-anemones troop with them. A most delicate pink are these, several blossoms on a stem; a most dainty plant. 
Jack-in-the-pulpit has called in a myriad fellow preachers and is in exhortation. The pulpits are new painted for the rernal circuit. The itinerants beg the giddy water beetles to give up dancing, but nothing will stop their gyrations. They waltz, wheel, polka, two-step, and quadrille, in a most amazing manner.

The dryad of the beech tree holds out her little glored hand, rery soft and beartiful. Can it be she wishes a release from her long imprisonment? Does she take us for some Rhocus? No; she merely offer's a greeting. There is no pledge nor promise. She would not on any account, leare this cool forest nook for the heat and dust of the city. She lores better the memory of the old days, and of the Indians who slept beneath her boughs.

We lore the long golden tassels of the birch, which, as we walk beneath the trees, are pendant from the topmost branches in graceful yellow fringes:-

"Upon the brink of some wood-nestled lakelet, Thy foliage, like the tresses of a Dryad,

Dripping about thy slim white stem, whose shadow

Slopes quivering down the water's dusky quiet.

Thou shrink'st as on her bath's edge would

Some startled Dryad.

Great opening buds of hickory as beautiful as flowers are fragrant with the odor of autumn nuts; the sweet-fern breathes out its dreamy perfume, and lazy butterflies wing their way through the bushes, seeking the love that flits 
before them. There are opening blossoms everywhere. Some familiar to us by homely titles borrowed by our colonial ancestors from old England; others that "know no name of ours," but wear sonorous titles of Roman and Greek origin. Perhaps the Indians who were real poets in their way, had sweet but uncouth names for all these treasures, which it would be well for us to know. Where their appellations have descended to us, our language of proper terms has been enriched, and we feel that we have inherited something: original and rare.

A very beautiful flower, common to both hemispheres, is in this month often found in our swamps. It is the buck-bean, or menyanthes, a member of the gentian family. It has long, sub-aqueous root stocks, from which spring the long-petioled compound leaves of three leaflets. The racemed flowers are borne on naked scopes and are white, or externally tinged with pink. Within, the divisions of the corolla are closely bearded with exquisite hairs.

The menyanthes is apt to grow provokingly out of one's reach from the shore. If one has long rubber boots it is delightful to wade in after it, and to stand waist deep amidst its tossing plumes. Like some Lorelei, it has tempted many an adventurer into the water.

While speaking of swamp plants, two should be mentioned that always appear to stand in fraternal relations - the golden ragwort and the painted cup. We find these friendships among 
plants, so that the experienced wood-lover from the presence of one will divine the vicinity of another. The ragwort is a very handsome composite. The painted cup, or, as the Western people more appropriately call it, "Indian paint brush," derives its charm, curiously enough, not from the flowers, which are small and greenish, but from the scarlet bracts. Occasionally one will be found with these yellow. The two plants together, when at all abundant, form a perfectly gorgeous carpet. The painted cup, which would be so beautiful in our gardens, is rendered uncultivable by its parasitic habit. It is attachecl to the roots of other plants. High up on the White Mountains there is another species of a pale color.

The fringed polygala, known also as flowering winter green, is a charming flower of this month, often found quite abundantly in low copses and borders of woods. The flower is magenta in color and very prettily fringed like an orchid. It is, however, in no way related to Arethusa and lady slipper. These are really orchids, the one a dainty little bulbous plant, of swamps; the other, at least the stemless species, grows in dry pine and oak woods. A rarer kind is the yellow, and still more beautiful than either is the showy lady slipper. This is white, tinged with red, and is found throughout northern New England.

The writer once had the fortune to meet the rare Calypso, and owns that life is well worth 
living. There were two plants at the foot of a pine tree in a deep wood. He has never seen a living plant of the genus since.

\section{CALYPSO.}

[A rare orchid of the North.]

Calypso, goddess of an ancient time, (I learn it not from any Grecian rhyme, And jet the story I can vouch is true), Beneath a pine tree lost her dainty shoe.

No workmanship of mortal can compare With what's exhibited in beauty there; And looking at the treasure 'neath the tree, The goddess' self I almost hope to see.

The tints of purple and the texture fine, The curres of beauty shown in every line, With fringes exquisite of golden hue, Perfect the wonders of the fairy shoe.

The goddess surely must have been in haste, Like Daphne, fleeing when Apollo chased; And leaving here her slipper by the way, Intends to find it on another day.

And will she come to seek it here or no ? The day is lengthening, but I cannot go Until I see her bring the absent mate Of this rare beauty, though the time is late.

I watch, but still no classic form I see;

Naught but the slipper 'neath the forest tree; And so, for fear of some purloining elf, The precious relic I secure myself.

Trilliums are quite representative May flowers, the showiest of which is very large, white, and 
nodding. As it matures it assumes a pink hie. The purple trillium or birthwort is known to everyone. Its color is not really purple. At its best it is a rich maroon. There is a vigor and decision about this plant that always appeals to one. It might easily be conventionalized in ornamentation. Still, the painted trillium, white with a red centre, or the nodding one even, is really prettier. All these plants derive their name from the prevalence of the number three in their leaves and flower parts. We have heard them appropriately called trinity lilies.

The "shy Linnrea," that perpetuates the name of the quaint old Swede, is very abundant in some parts of New England, filling the whole forest with its sweet and delicate perfume. It trails along the ground, throwing up at frequent interrals a stem which bears two pretty nodding bells. Near it, particularly as one approaches the mountains, is found the rood-sorrel, a peculiarly charming and modest plant. Its white blossoms are streaked with pink.

In a similar locality look for the mitre-wort or the bishop's-cap, and its cousin called falsemitre-wort. The botanical names of these plants are so pretty and so easy to remember that they ought to be adopted. Let us then call the first, with its tiny flowers like arrested snow-flakes, Mitella, and its relative Tiarella. The last also has white flower and heart-shaped leares.

As one walks through the deeper and colder woods of our region, he comes all at once upon 
beds of a plant whose glossy entire leaves suggest the lily of the valley. These leaves are themselves very beautiful, and the nodding lilylike yellowish green flowers, charming. The plant is, a Clintonia.

A more conspicuous liliaceous plant is, howerer, the adder's tongue or dog-tooth-violet. It is in no sense a violet as its flowers at once show. These are best seen in open sunlight. The plant grows along river and stream banks always in beautiful places and has glossy leaves mottled with reddish brown. Growing in extensive beds only a few specimens, comparatively, blossom. The bulbs are well down towards China and have to be struggled for. These plants, if removed to a garden, increase and multiply, though they do not always bloom.

A representative New England plant, at least for the northern zone, is the bunch-berry or dwarf cornel. This affords another instance of a plant where the bracts are more conspicuous than the flowers. These are aggregated in a head, which is surrounded by four snowy bracts. The flowering dogwood-one of our handsomest trees, also a May-flowering plant, shows the same thing on the large scale. They make the woods very gay with their large white clusters.

There is a little rosaceous shrub in swampy places, known as chokeberry. It has white flowers and deep maroon-colored anthers. It belongs to the same genus with the apple, pear, and mountain-ash. The wild geranium is very 
common in this month. It is distinguished afar off by its large, light purple, or lavender-colored flowers. These wilt very easily, and in order to keep them fresh one should carry a tin box or case in which to preserve them. A pasteboard envelope box is better than nothing, and, at a pinch, they may be even wrapped in paper. A box is always desirable. It is pitiable to see a lot of beautiful flowers withering in the collector's hands, and they are sure to do so if not protected from sunlight and air.

Every body knows the pretty little false Solomon's-seal, or false lily-of-the-valley. It often grows in solid beds about the base of some tree, and has glossy leaves and tiny white flowers. A tall species grows in the woods. The true Solomon's-seal is known by the impressions on its rootstock, and has nodding greenish, or in the large species, green and white, very fragrant bells.

Near the coast the barberry is now in flower, gay with yellow pendulous racemes of a disagreeable odor. The stamens are curiously sensitive, and when touched, move forward towards the pistil--

"All down the loose-walled lanes in archin' bowers

The barb'ry droops its strings o' golden flowers,

Whose shrinkin' hearts the school gals love to try,

With pins, - they'll worry yourn so, boys, bimeby!"

If we examine the leaves of barberry we will probably find on some of them certain orangecolored spots caused by a peculiar fungus, com- 
monly supposed to cause rust in wheat when barberry bushes grow near wheat fields. This opinion, long regarded as a rural superstition, is now known to be correct. Careful study indicates that the fungus has an alternation of generations. The form which inhabits the barberry produces the one which injures wheat. Sir Joseph Banks, it is said, first called attention to the possible relationship of the two apparently dissimilar forms, and subsequent observations by De Bary confirmed the wisdom of his suggestion. The history of vaccination should have taught scientific men not to reject too suddenly even the crude notions of the peasantry. Under the veil of superstition the wise may often detect the beauty of truth.

Several shrubs of surpassing beauty blossom in May. Pre-eminently first is the pink azalea, often erroneously called honeysuckle. It is also frequently known as swamp-cheese from the juicy excrescences which occur on the foliage. Azaleas are to-day ranked with rhododendrons, the number of stamens no longer seeming to separate them. The azaleas, too, as in this lovely one of ours, have more fumnel-form or trumpet-shaped corollas. The bushes afford a gorgeous mass of color, often transcending pink and passing into the deepest red.

True honeysuckles open in this month, the pretty bush or fly honeysuckle, and the mountain fly honeysuckle. The first is taller, indeed quite a bush, and has handsome red berries. 
The other is a small shrub in swampy places, with pale yellow flowers succeeded by blue berries.

The pea family is represented by the wild lupine, a plant so generous in its bloom as often to color a whole hillside with blue. The flowers are borne in erect racemes, and the palmate foliage is most exquisite. In early morning one often finds a rare gem of dew sparkling from the very middle of the leaflets. There is no hesitation about gathering all one wants of this pretty flower; the supply is unlimited.

As Hosea Biglow says, "I don't love your cat'logue style." It is our desire to avoid that error so far as possible. We cannot enumerate every flower of the month, and it would be tedious to do so. Indeed, some favorite plant may be omitted. Even if this is so, the reader can be very sure that in looking for those here recorded he will most likely find his own. 

JUNE. 



\section{JUNE.}

" Our Spring gits everythin' in tune

An' gives one leap from Aperl into June."

- Lorell.

About the time that young students are projecting their graduation speeches, the meadows. put on their most glorious aspect. There are certain plants that seem especially to court the association of grasses, much to the annoyance of farmers and the delight of artists. Of all pernicious weeds in New England the whiteweed or ox-eye daisy is perhaps the worst; but nothing can be more beautiful than a field of marguerites. We gather great sheaves of them for household decoration. Youthful maidens count their rays as did Gretchen to ascertain the state of their lovers' affections. At the same time with the daisies come the clover blossoms to afford the needed red to the picture. The bees quickly find them out, and reap a rich harvest of honey from their nectar-bearing flowers.

Readers of Darwin will recall how he traces: out the connection between cats and clover. Bees visit the clover blossoms for honey, but: moles and mice destroy bees. On the other hand, cats wage relentless war upon mice and moles. So, from the good old maiden ladies of 
Cranford who own the cats, there is a natural and logical sequence to the clover field in full fruition.

Dandelions have now set their stars everywhere, in lawns, in meadows, by roadsides, and away in the woods even, where their balloonlike fruits have wandered, wind-borne. What, by the way, can be more beautiful than the feathery globes of dandelion. Could one choose a more exquisite type of evanescence? A mere breath is sufficient to release the little messengers. We love to follow them in imagination and trace their various fates. There is nothing in all this beautiful world more lovely than a group of young children playing with this lavish gold of Nature, tossing about the gleaming coin, or binding themselves together with fragile chains.

It is surprising how many of these familiar plants are of Old World origin. There are the buttercups, for instance, the early bulbous one, as well as the tall and acrid later species. No one could guess that they were not to the "manner born." We could ill spare their glad faces from our fields. Perhaps the prettiest of all is the creeping species. It has the largest flowers, and these have a tendency to double. These buttercups or crow-feet are rare in the West.

The long-leaved plantain is a characteristic meadow plant. It is sometimes known as ribgrass, owing to the long and parallel reins of its 
leaves, which still are not those of an exogen. The flowers borne in spikes on long naked stalks, are of scaly texture and inconspicuous, except as regards the long filaments, upon which the anthers are pendulous. The styles first project in these plants, and the stamens later after the stigmas have become functionless. Hence re-action must take place between individuals of distinct spikes, an arrangement to prevent close breeding.

Soon we will find in the meadows a rather pretty little blue flower of the mint family, the self-heal, or heal-all. It has the square stem, opposite leaves, and two-lipped corolla of its order, but it is without the pungent taste and smell. Albino conditions of these flowers are not uncommon. Indeed, near the summit of Mt. Wachusett, we have seen a whole bed of a white flowered form. Any flower, by the way, is liable to take on a white condition. Now-adays it is hardly worth recording.

A much smaller plant than the self-heal-belonging to the figwort family, is the reronica or speedwell, of which there are a number of species. The blue one is an especial beanty. Of it Tennyson says:

"The little speedwell's darling blue."

The sheep-sorrel comes at about the same time, and when it is abundant must indicate poor soil or negligent husbandry. It is often, however, very effective in a landscape, giving a 
rich, warm, red to distant slopes at a time when the views are, if anything, too crudely green.

After the white daisies have ceased to represent the rast composite family, the cone-flowers or Rudbeckias put in an appearance. These are similarly constructed but are larger, and have a conical, chocolate-colored disk and orange rays.

Our native lilies might be classed as meadow plants. They are among the most beautiful of our wild flowers. The times of blooming, and the kinds, perhaps, will vary with different parts of New England. In Rhode Island the first to appear is the so-called Philadelphian lily. It is known by its deep red, erect chalice, making it a conspicuous object in the meadows. Sometimes, but not commonly, a stalk bears sereral flowers. The cone-shaped sepals are not recurved as in later species, so that the flower forms a cup-a sort of Holy Grail that well rewards the seeker. It comes at the time when the sweet Pogonia succeeds its cousin Arethusa in the swamps. We shall say more of this anon.

The second species of lily to appear is the Canadian. It has a much lighter, orange-yellow flower, spotted on the inside with brown. The large, bell-shaped flowers are nodding-one or several on a stalk - and the sepals which in other species are long stalked, are here without stems or claws.

Still later comes the superb lily or Turk's-cap, from three to seven feet in height, with showy 
orange and yellow flowers, spotted within, more brilliant and glossy than either of the others.

Our American lilies are quite commonly cultirated abroad and should be here. There is no genus with which the gardener has done more, some of the crosses obtained being among the most magnificent of flowers. It may be of interest to note that some authorities think that the famous "lilies of the field" were not lilies at all, but the showy red anemones of Syria. However this may be we prefer our Scripture unrevised. The anemones of the field, though these oriental ones are indeed gorgeous, do not affect us as do the regal lilies surpassing the raiment of eren Solomon.

The old French kings were men of taste when they chose the flag-lily for their royal emblem. It is truly a regal plant. "Born to the purple, born to joy and pleasance," it unfolds its velrety petals and stands king-like in the meadows. It is perhaps unnecessary to say that flag-lilies are not true lilies. The genus Iris, indeed, is of another family. It has a perianth united into one piece below and coherent with the ovary, a petaloid stigma, and three out-facing stamens. In the leaves, too, it is quite different from lilies. Our American species of iris are not so beautiful as the various cultivated foreigners; they make a concession to our democratic institutions. Still, there is enough of the pomp of courts about them to make one know that they would shine therein. Points of official eti- 
quette would come easily to them. They have the right divine. Certain meadows, prolific of little else, are productive of flag-lilies. Sprague has well represented them in the "Wild Flowers of America," catching their very grace and pose. We have a smaller wild spe(cies, the Virginian or prismatic Iris, much more delicate.

The orris-root of commerce (a corruption of iris-root) has the odor of violets, and is largely used in perfumery. It is produced by the rodstock of Iris florentina, a species with large white flowers, in cultivation. Our little wild, blue-eyed grass belongs to the iris family, and is very pretty. Often a field will be gay with it. Perhaps our native flags would thrive in cultivation. Still, they can never look so lovely as in their own chosen meadows in the sunny days of June.

Delightful meadow plants; there are none other like them, these beloved blossoms from the old home over seas. Did not Chancer, Spenser, Shakspeare, Milton, wander among them and sing their praises? Has not Tennyson made them immortal? Among them we stroll as with the gods on Hymettus. Have we not bees here, velvet fellows, and honey as sweet as theirs? Like a child we wade kneedeep amidst these glorious blooms. The daisies break in white surf around us; the buttercups ride on the billows. Like Wordsworth's daffodils, they will dwell in the memory and soothe 
in solitude. What a sky bends over them in these June days-the days that will come despite the caprices of May! Italy can have no bluer heaven than ours, or greener foliage, or fleecier clouds.

It is curious to note, from year to year, how new plants turn up from Europe or elsewhere. What we know as "waste places," those unsightly heaps where refuse is thrown in cities, are often rich in these waifs. Often will one pick up a rarity. Thus, the orange hawk-weed and the hybrid clover came in some years ago. Both are now common.

Fair June is at her best when the wild roses open their blossoms to the sun. Gathered about the stone walls of New England, or in copses in the fields, or fringing the wild seacliffs, where they are always of exceptional brilliancy, they come quietly into bloom. It is peculiarly inappropriate to say of them they burst into flower. Creatures so gentle have not so demonstrative an evolution. All their movements are, like their outlines, graceful. The colors are the highest and most delicate conceivable; an embodied blush; a sun-rise glow enshrined. The perfume is as sweet as the memory of the loved and lost. It is not overpowering, but pervasive, subtle, delicious, satisfying.

In the time of the roses we keep a cluster of the native kinds, the full-blown flowers and opening buds, upon the table. They hallow our 
thonghts and make us at peace with all men. They are, like all precious things, transient. Hardly can one say, "How admirable!" when the fair petals fall upon the paper. With the splendid momntain-laurel, they are "Commencement flowers," opening into loveliness at the time when the young graduates go forth into real life.

We do not underrate the roses of the garden when we express our preference for these wildling's. The undoubled flower, as Nature designed it, is dearer to us than the long-fringed and much-tortured hot-house forms, superb as those often are. In the early morning, when the dew beads its petals, we seek the rose as if in derotion. Surely no sweeter incense rises to heaven!

In the prized cultivated roses the stamens have been changed into petals, but in the wild rose we have the original and healthy flower, with five petals, maltered by the art of man, and sweet in native innocence. Its fragrance far surpasses most garden roses. Were it only more permanent it would vie with the roses of the East. The flowers, however, are very evanescent, opening generally for one day only, when the delicate petals are scattered by the breeze. They are most charming when in bud. Incleed the best way to pluck them is in the afternoon, when they will open for one next morning.

As we ride through some wild wood road in 
this month, where the shrubbery is undisturbed, the wayside may be bordered with masses of the pink blossoms of mountain-laurel. These are as fine as any rhododendrons. Beautiful with its glossy foliage at any season, the laurel is now gorgeous. It is a shame that it is so persecuted. It is not Apollo that pursues our Daphne, but small boys who seek the roots for rustic baskets, or decorators who gather the leaves for winter wreaths, or flower lovers who come for the blossoms.

In farored localities the shrub may attain a height of ten or fifteen feet and form a dense thicket. Every one will remember the elegant appearance of the flowers. These are very curious. The corolla is provided with ten pockets, indicated exteriorly by the same number of projections. In these depressions are lodged the anthers. The filaments are elastic and are bent over and secured in the pockets. A slight disturbance, however, causes them to retract, release the tension, and throw the pollen as from a little catapult. This may not strike the stigma of its own flower; indeed the design seems to be that it should not. Cross-fertilization is the idea aimed at. Bees are generally the disturbing agents and often receive the charge of pollen on their own bodies. The action is assisted by the peculiar arrangement of the anthers, which open by a chink at the top. Besides the name of mountain-laurel, this plant is now known by its scientific title, Kalmia. It 
was named after the botanist Peter Kalm. It is also called spoon-wood and calico-bush. Its foliage is often considered poisonous to cattle, but its effects are not definitely known. It is as well not to let small children handle it, lest with the instinct of childhood, they should put the leaves or blossoms in the mouth.

We hare two other species of Kalmia, one the common lambkill, low, and with deep red flowers; the other found farther north-or on mountains, with glaucous leares.

Pond lilies begin to make their appearance in June, but continue all summer. The flower of this plant is an inspiration. No one looks upon it without feeling soothed and ennobled. The Oriental nations, with the poetry that distinguishes them, take the lotus as the symbol of deity. In its pure bosom reposes the great Buddha in his condition of perfect rest; for a similar Nirvana all mortals are seeking.

The sacred lotus, though not identical with our pond-lily, is a species of the same family. It is nearer like the nelumbium of the Western States.

Nothing can be more beautiful than our own Nymphra, with its pure white petals tinged with shell-like pink, and its cool, delicious perfume, suggesting embowered ponds and summer shade.

It is no easy matter to gather pond lilies; indeed, it is proverbially difficult to attain anything worth having. These plants, in the first 
place, grow provokingly out of reach from the land. To pluck them one has either to take a boat or play the Leander. It is better to embark in a boat, for swimming arnong the long, slippery and snake-like stems of pond lilies is rather dangerous business. They enwrap themselves about one and threaten, like some Lorelei, to pull him under. But in a boat he is safe, and can sail among the floating stars in peace.

The blossoms close in the afternoon, and are drawn near to or beneath the water; they require to bathe their bonny faces now and then. Linnæus was as fine a poet as the Hindoos when he named the genus Tymplecer, for what could be more sacred to the water nymphs than this lovely pond flower, surpassing the sweetness of their own breath? Perhaps our plant is a very nymph, who, disclaining the love of the gods, changed herself into this flower and abides with us forever.

The leaves of the plant are somewhat heartshaped and rest flat upon the surface of the water till a passing breeze tosses them up and shows the reddened undersides.

Attention has often been called to the fact that a pond-lily, the very type of purity and innocence, arises from slimy and loathsome mud. Here is a fine chance to moralize, but we wisely forbear.

Near the pond-lily, and as a foil to its beauty, grows its yellow cousin. It is not pretty and its color is offensive. Perhaps it is yellow with 
jealousy of its exquisite companion. A little flower, often mistaken for a diminutive pondlily, is the floating heart, but this really belongs to the gentian family. The water-shield, too, occurs in some ponds; it has the stems coated with transparent mucilage, which disappears in drying. The flowers are small and inconspicuous. The deep pink pond-lily is a sport merely from the ordinary. It is found near Cape Cod, and in some other localities.

In cold, damp woods, especially under pines, is found the one-flowered Pyrola. Its botanical name, Moneses, means "single delight," and surely nothing could be prettier. The waxy flower is white or rose-colored, and with a most delicious fragrance. The plants grow in beds or clumps.

In very similar places one meets with the equally odorous and charming partridge-berry, a trailing evergreen herb known to everyone for its red berries, which persist through the winter. The pure white flowers are densely bearded within, and are di-morphic like their cousins, the bluets, and for the same purpose. The plant perpetuates the name of Mitchell, a Virginian botanist and correspondent of Linnæeus.

Nost of the tropical members of the orchis family love to perch themselves airily upon the branches or trunks of trees, and their position aids in deceiving the observer as to their nature. $\mathrm{He}$ fancies some gorgeous insect has but alighted for a moment, and expects to see it flit 
to the nearest flower. One would naturally suppose them to be parasites, but such is not the case. The boughs of the trees, and the nooks of rocks are but their resting places-the air is their sustenance. Their delicate beauty disdains to be nourished by the earth which supports the neighboring plants. Nothing but the pure air of heaven can be moulded into forms of such ethereal beauty. So perfect is their resemblance to butterflies and bees that insects themselves are said to be deceived and enticed towards them.

This apparently trivial fact assumes a deep significance in view of the discoveries of Darwin and others, who have proved by careful observation that most of the Orchidacece are unable to produce seed except through the agency of insects, who, in their search for nectar, carry the fertilizing pollen from one flower to another. The organs of the insect and the plant were evidently planned for the purpose of assisting in cross-fertilization. It is asserted that some orchids would perish from the earth if their living attendants were destroyed.

Now, none of our northern orchids are airplants. All, like the lady's-slipper and Arethusa, are terrestrial. Still, they bear the signmanual of their order. The structure is, in effect, the same as in the most gorgeous tropical species. June gives us several lovely members of this family. Following the Arethusa, with a. less interval, comes the pink Pogonia in the 
bogs. It is sometimes mistaken for Arethusa, but is of lighter color, has a leaf midway of the stem, and a powerful and delicious fragrance, suggesting mignonette and violets. In similar localities grows the Calopogon. This plant shows several magenta-colored flowers, on a slender stem, and has the bearded lip standing like a crest at the top of the perianth. In June appears, also, the larger purple-fringed orchis, one of the most superb of our wild flowers.

Tre lore to lie, on these summer afternoons, in the shade of forest trees. Learing the dusty city far behind, we seek some leafy nook, and, lulled by the tinkle of distant cow-bells, repose, half dreaming, on the relret moss. Through the foliage, just rustled by the breath of the south wind, we catch glimpses of the beautiful river, as it flows onward to the ocean, here and there dotted by the white sail of some ship that goes out, with the trusting faith of youth, into unknown storms, or still more dangerous calms. Now and then a great, full-laden bee blunders against our face, and, with a buzz of apology, flies off with his load of pollen treasure; then a gaudy butterfly, banded with black and yellow, drops upon us, like the petal of some tropic flower.

Afar off from the shrubbery comes the music of the thrush, as, in peasant garb of brown, he woos his gentle mate. Above us is the deep blue of the sky, flecked by billowy clouds, beyond which the fancy soars to the Infinite. 
Even the ants, who laborionsly pursue their mysterious arocations, seem in perfect keeping with the hour. We like to contrast our present laziness with their unceasing industry, and really feel commiseration for these mites who take no rest. 

JULY. 


\section{THE EVENING PRIMROSE.}

I stood in awe before a simple flowerExpanding quietly at evening hour, And watched to see each petal fair unfold 'Neath Nature's touch to form a cross of gold.

I merely whispered, “ This is sacred ground; The Holy Grail I now, at length, have found ; No longer need I weary in the yuest; Iy search is o'er : I win eternal rest ! 


\section{JULY.}

"Find the stubborn thistle bursting Into glossy purples, which out-redden All voluptuous garden roses."

-Tennyson.

One cannot definitely relegate any particular flower to one special month. Thus, in July we still find the white daisies, the wild roses, lilies and pond-lilies abundant. The orange-colored Rudbeckias or cone-flowers are now in their glory, though they appeared first in June. There is more of barbaric and Oriental splendor to them, with their showy rays and dark chocolate centre. To see a child with gathered sheaves of them in her arms is to view a picture for a poet. They are distinctly meadow flowers, coming, it is said, from the West. The Rudbeckias is handsome enough for a garden, yet under the accepted definition of a weed, that it is "a plant growing where it is not wanted," this is a weed. It will thus be seen that circumstances very much influence one's opinion as to conventions.

Another beautiful plant beginning to bloom in July, and continuing to flower until late autumn, is the so-called "butter-and-eggs," or "toad-flax," or wild "snap-dragon." It is a member of the great figwort family, in which $5 *$ 
we find the mulleins, forglores and speedwells. Darlington characterizes it as a "vile weed;" we think he might have spared the adjective. It is said to have been introduced from England as a garden flower. He was a man of taste who thought it worthy of cultivation, for nothing can be prettier than its delicate yellow, twolipped and spurred corolla, with orange palate. Normally the flower is very irregular and unsymmetrical, having only four stamens, but if one watches long enough during one or many summer's he may chance to find what old Linnaus called its "peloric" state, with five spurs instead of one, and with a full complement of five stamens. These flowers are usually late ones, at the top of the raceme, where they are not crowded, and have full play for development. By means of its creeping roots the plant forms large patches, and is difficult to eradicate.

Belonging to the same family is the mothmullein, much too pretty to be called a weed. The flower's, which are either a waxy white, or, more rarely, yellow, are nearly regular, and have five stamens, clothed near the base with violet hairs. They succeed each other in a long raceme, which often has, in autumn, a second flowering. The pods survive as conspicuous objects till winter. The blossoms have all the delicacy, when fresh, of those of the peach or apple; they are, though transient, exquisite in a bouquet.

Frequently we meet with the wild bind-weed, 
twining about shrubbery, and, in the early morning, holding out a large, delicate, pink or white flower, like the morning-glory. This plant loves the sea-side and is a marked feature in meadows. Transplanted to a garden, these perennial plants spread terribly by their subterranean stems, and become a nuisance. The foliage is infested by a most beautiful beetle, iridescent as the diamond.

True morning-glories, by the way, are about as satisfactory as any flower one can possess. Old-fashioned they may be, but of that fashion that is erer beautiful. They need no special care, but, sowing themselves year after year, come up and climb oyer our fences and trellises, forming bowers of exquisite bloom. Beginning to open in midsummer, they do not strike their tents until the frost compels them to withdraw. Humming-birds, moths, and bees honor their silken parilions and explore them for sweets. Their funnel-formed flowers are of many and varied hues-all of them delicate and admirable. The whole growth of the plant is interesting, from the time it breaks ont of its husk and, straightening its crumpled seed-leaves, expands into the light and air, up through its mere vegetative growth, when the heart-shaped, or halbert-shaped leares appear, until such time as it actually becomes the "glory of the morning!" Stepping out into the garden at breakfast-time, one has a rare show of beauty to reward him. High up in the grape-rines, and in the old apple 
tree, hang the pink, purple and white bells, all the more lovely for their extreme evanescence. "Loreliest of lovely things are they, on earth, that soonest pass away." Nothing is more ephemeral than a morning-glory. It erolves by some mysterious unfolding into a thing of beauty. In a few hours it has done its work and coils in upon itself. "Where is that Promethean heat which can its light relume?" It has gone as a sweet soul breathes itself away to heaven.

There are many ways of doing nothing in the long vacation; all of them more or less profitable. In the first place, it advantageth a man to swing in a hammock-especially if he be on the sea-shore; the swaying couch and maritime outlook causing him to ponder much concerning the two great deeps that meet yonder on the horizon. For reading a light novel there is no place like a hammock. Moreorer, since we learned somewhere that Macaulay delighted in trashy fiction, and spent whole nights reading dime novels or their English equiralent, we have felt less apologetic in regard to our own course. Next to a good work of fiction there is nothing so interesting as a weak one. The comedy one reads between the lines will often atone for many wearisome paragraphs. Just as we find the farce set down in the bills is not half so funny as the tragic prelude.

But the most delightful of romances, or the sprightliest essay, or most brilliant correspond- 
ence, will not always fix the attention. The eyes wander from the book to the waving green of the woods, and through the quirering leares to the blue abore, or out to the sail-dotted ocean. From our position we can note the daisied meadows sweeping to the sea. Orer these the bob-o'-links are sporting. . The kingbird, watching his chance, darts down on some unwary insect. Sweet, drowsy odors arise from wood and field. Even the plants seem indulging in a rest.

Every collector knows that there really is a lull period between spring and true summer. The early flowers are gone; the summer ones have not yet come, or have appeared furtively. In the roods scarcely anything is then foundcow-wheat possibly, or copses of New Jerseytea, or a bed of early sunflowers. The plants of this period are mainly to be sought in swamps, where the shrubby loosestrife trails its purple clusters, or the white azalea fills the air with its spicy aroma.

In brackish marshes near the sea one will find a flower so splendid that he will doubt if it can be native. This is the rose-mallow, whose superb pink corollas attract one from afar. The corolla is fire or six inches in diameter, and may or may not have a crimson eye. Peculiarly delicate and refined is the texture of the petals. Surely a choice and aristocratic flower.

A midsummer bouquet is certainly something gorgeous. Besides the field lilies we can in- 
clude the white and orange daisies, the various species of yellow loosestrife (all pretty), the purple loosestrife (no relation of the other), and great tufts of feathery meadow-rue. In skilled hands these naturally fall into place and produce a striking harmony. The brilliant tints of these blossoms always remind one of Persian or Turkish rugs and carpets, or of Hindoo tapestry. Summer has exhausted upon them her wealth of color. They seem too warm and glowing for a climate where in winter the mercury touches the cipher. How freely is this wealth and luxury offered. It is without money and without price!

The meadow-rue here spoken of is a tall plant, often five or more feet in height, tufting out into feathery plumes. It makes an elegant addition to a bouquet.

Perhaps it is needless to say that there are some plants that do not blend well with those here mentioned. Thus the little meadowbeauty, a very dainty thing in itself, is of that peculiar solferino tint that Nature loves, but which kills any other color. It is astonishing how often we see it in flowers. Thus Arethusa, Pogonia, Calopogon, Fire-weed and many other plants are so painted. In anything but a flower the color seems atrocious, but this may be only a matter of temporary convention. Our love of colors varies most capriciously like the size of our sleeves or the height of our collars.

If one strolls along the bank of some wooded 
brook in this month, his eyes will be gladdened by a brilliant show of the jewel-weed, wild touch-me-not, or balsam. There are two species in New England, the most common having orange-colored flowers, in shape singularly like a hunter's horn. Indeed, we have heard the name applied to it. This was one of the first. plants from our region described and figured. It is pretty to see how the dew collects in shining beads upon its leaves. Then the pods ripen they scatter their seeds by a sudden rending and twisting of the valves. In the same copse will be seen a mass of tiny white flowers of bed-straw, or "babies-breath." The enchanter's night-shiade, too, may be seen along the rivulet. Farther north, by river banks and on tops of the lower mountains, the lovely blue hare-bells tremble in the breeze. The finest show of these we can recall was on the summit of Mount Willard, in the Crawford Notch of the White Mountains. It is the same as the bluebell of Scotland.

On the borders of ponds and streams-indeed, sometimes well out into the water-grow tall ranks of pickerel weeds, with blue spikes of flowers. Mixed with these is the arrow-arum, with fine, generous leaves, and a long, narrow, fluted spathe on the plan of a calla. Somehow beginners in botany are apt to pass over this plant, perhaps because it grows in the water. This is at least the reason that many very showy bladder-worts, yellow and purple, are unknown 
to young collectors. We have seen the surface of a pond golden with the common bladderwort, the Howers of which resemble snap-clragons. Mrs. Treat and others have told us how the leaves are expert insect catchers.

Speaking of insectivorous plants, this is the month in which to see the famed sun-dews in flower. No plants, perhaps, have had more said of them. Old Erasmus Darwin sung their loves and his grandson wrote their history. Many another has essayed to tell the action of the leares. It will be recaller that those of the common species are round and beset with glandular hairs. These are sticky at the ends and glitter in the light, giving rise to the popular name. Insects alighting upon these hairs are mired; the hairs incurve; the whole leaf at length becomes concave; a gastric juice is secreted, and the creatures actually digested. The plants are cousins of the famous Temus fly-trap of North Carolina. In Southern Massachusetts the red-flowered species, with long, snake-like leares, is found. It may yet turn up in Rhode Island. Sun-dews live, as a rule, in peat-bog's, places always peculiarly rich in plants. In peat, for instance, grows the curious and handsome pitcher plant, whose leaves also catch insects, but in a quite different way from the sun-dew. Its peculiar maroon and lemon-yellow flowers belong rather to June. A fine specimen of it, with a dozen or more pitchers, is a thing never to be forgotten. The have found it from 
Southern New England far up into New Brunswick.

The milk-weeds, or silk-weeds, are characteristic July flowers. We have eight species in New England. The common species is known to every one. The handsomest is the so-called butterfly-weed, with orange-colored flowers, an extremely showy thing. A very delicate little plant is the four-leaved milk-weed, found in rocky places, with pale pink and white flowers. The poke milk-weed grows about moist copses, especially in hilly regions. Tre hare seen it abundantly about Mount Wachusett. The pedicals are loose and nodding, the corolla lobes greenish, and the hoods white. The leaves are pointed at both ends, and are of much less firm texture than the common milk-weed. All these plants, and in non-essentials they are rery varied, have the same peculiar structure, too recondite to describe here. The fruit is a poct, which, when it opens, displays the flat seeds beautifully imbricated over each other and tied down, as it were, by their hair. This is a tuft of delicate, silky fibres which crowns each seed, and later expanding into a parachute, wafts the seed away.

Very near relations of the milk-weeds are the dog-banes, of which there are two species. One is known as the spreading dog-bane, and is found along walls, in thickets, or in pastures. It has pretty, rose-colored bells. The other, called Indian-hemp, is not particularly attractive. 
Both are infested by a rery handsome green beetle, the " gilded dandy."

In sandy districts near the coast the goldentopped aster corers a large extent of country. It is a low, almost bushy plant. Other composites of this month are wild sunflowers, the white-topped aster (which is not a true aster), and the showy chicory, which in Eastern Massachusetts opens its great blue disks in the morning to close entirely by afternoon. Thistles, too, begin to appear, and though few seem to know it, one or two golden-rods.

The finest shrubs of the month are the button-bush, seen in and about swamps, the white and odorous azalea, and the great laurel, rosebay or rhododendron.

While rare in most of New England, this elegant plant is common and rigorous in Rhode Island, near Wickford and Kingston, where it grows from fifteen to twenty feet in height.

\section{"Its cups of tender snow,}

Touched with a rosy glow,

And warm, sweet shadows, trembling orer all."

Humble relations of these stately plants are the shin-leares, or pyrolas-sometimes also called wintergreen, though that name more properly belongs to the pretty Gaultheria. The pyrolas are low, smooth perennial herbs, with racemes of nodding, wax-like, white or pinkish flowers. They affect cold woods, where, at the time of their blooming, one finds little else. 
We have several species. They are close relations of the Indian-pipes, those ghostly and mysterious flowers that one now finds in deep forests.

"The wonder by her was formed

Who stands supreme in power ;

To show that life by the spirit cones,

She gave us a soulless flower."

NEW ENGLAND ALPINES.

“Hills peep o'er hills, and Alps on Alps arise."

-Pope.

This is the season for mountain exploration. There is no such fascinating field for collecting as a mountain top. The plants there found are intrinsically so pretty; they snuggle away in such quaint crannies and crevices, where they must be earnestly sought for, often at peril of life and limb; they are so rare and precious, things that we may by good fortune see twice only in a lifetime; and, lastly, they are set in such a ravishing environment, the eternal hills, and the glory of sky and cloud. Who can ever forget a day on a mountain top? The whole landscape is one's own. Nominally, perhaps, some one else possesses it, but it is ours by the divine right of discovery and appreciation.

Moreover, by ascending a mountain like Mount Washington or Mount Lafayette, one sees in epitome the zones of vegetation which he could otherwise only observe by extended 
travel. For altitude affects regetation much as does latitude; plants become more and more boreal as one ascends, until, if the mountain be at all high, a region will be attained where vegetation is reduced to mere lichens.

Mount Lafayette is one of the finest peaks of our whole New England region. The ascent, while perhaps tedious, or eren hard, is nowhere dangerous. Of course, if one left the beaten track, he could find difficulties and dangers even.

The trail starts from near the Profile House, and, passing through some interesting woods, suddenly climbs towards Eagle Cliff. This is the stupendous ridge one sees to the left of the valley as he drives in from Franconia. Here, on the pathway, is a large boulder, where it is conrenient to rest after the first third of the climb. From it there is a glorious view of the famed Profile itself, "the great stone face," always so majestic and awe-inspiring. The eye also sweeps down the valley towards the Flume. The bugle from Echo Lake reverberates through the hills, and sets "the wild echoes flying." The whole scene is so charming, the rest so grateful, that one remonstrates at the order to "move on." But time in mountain climbing is an inexorable commander; he allows no loitering. Everyone must give an account of himself.

For some little distance now the path is lerel. Then we come to a cool, delicious spring. Te 
must now brace up for the ascent, for the rest of the climb is serious. Every now and then windfalls bar the way. These one must climb over or pass under. There are bits of corduroy road much out of repair; the brakes have sprung up in the pathway; the trail itself has become the bed of a miniature torrent.

An alpine-stock is of great assistance. Sometimes one can bear his whole weight upon it, especially in descent. As we are now reaching a tolerable altitude, we begin to examine the plants. The most striking feature of the regetation is afforded by the billowy masses of moss that clothe the hillside, the rocks, and the trees. These mosses are of infinite variety and beauty. The mountain-ash is occasionally seen on the road. This is the "rowan" of the Scotch, and figures in many a legend. In late August and September its red berries are a striking feature in our mountain scenery. Birches, beeches, and spruces are the prevalent trees. Everywhere in the woods along the path is a mountain form of golden-rod. It has the beads disposed in the axils of the rather broad, deeply-serrated leaves. The flowers form a sort of wand. The wood or acuminate-leaved aster is also seen. In the spring these same woods are full of flowers, as we now note the leaves of Linnæa, wood-sorrel and cloud-berry.

Well up towards the limit of ordinary trees one is surprised to see large, vigorous specimens of the white or false hellebore, which the mind asso- 
ciates rather with low ground. As a matter of fact, it is a marsh here, and we find a second gushing spring:

At last we are in the dwarf forest, the little weird, ancient, gnome-like woods ; trees to delight Dore, they are so full of apparent action; so grotesque. They look as if they had been born old, like one of the heroes of Bab Ballads. Among them we pause to lunch.

Who can fitly sing those noonings among the eternal hills? There are puns in plenty; songs, shouts, and hot coffee, for we have, with due precautions, built a fire.

Strengthened by the repast, and the pause, which should not be so long as to "stiffen the sinews," we start on, passing a little lake which we long to explore. A very mysterious and silent pool is this-a lily or two gemming its surface, its banks buried in sedge and juniper. Many fine things grow about it.

A cloud still caps the distant summit, but in a moment it is gone. We seize the opportunity to hurry on, and we are soon amidst the subalpine flowers. The golden petals of Peck's geum are seen everywhere, and the snow-white bloom of the alpine sandwort. This is often erroneously spoken of as "mountain daisy." It really is nearer a chickweed. We see two species of rattlesnake root, both to bloom later. Round, moss-like bells of diapensia are everywhere, with pretty flowers. This is a true arctic plant found in both hemispheres. The golden- 
rods now seen are only a few inches in height; but the heads are large and showy.

It should be noted that before we come to the last ascent we have passed through an extended district of dwarf firs, so closely compacted that it would seem possible to walk over the tops. Even these little trees yield finally to pygmy willows, birches and spruces, that closely hug the rocks and spread out their branches from a common centre. A section of a stem of such a plant shows it to be in age a tree; in size it is not eren a shrub. Stress of weather has caused it to pull in all sail, and to expose as little surface to the winds as possible. Herbaceous plants that live at this elevation, or still higher on Washington and Adams, have a very short season of growth, and must make the best of it.

There are in round numbers about only forty true alpines found in our region. These are confined to the highest peaks of the White Mountain range, to Mount Katahdin, and Mount Mansfield. The region about the last peak has proved particularly prolific of rare plants, some of which are confined to this one locality.

A list of our alpines may prove interesting. We give both common and scientific names:

Dwarf Bitter-cress, Cardamine belliclifolia, L. Narsh Violet, Viola palustris, L.

Moss-campion, Silene acautis, L.

Sibbaldia, Sibbaldia procumbens, L.

Alpine cinque-foil, Potentilla frigida, Vill.

Mountain Saxifrage, Saxifraga oppositifotia, L. 
Alpine-brook Saxifrage, Saxifiaga mivularis, L.

Saxifreng Aizöon, L.

Sarifiega stellaris, L., var. comosa, Wild.

Yellow Mountain Saxifrage, Suxifraga ciazoides, L.

Alpine Willow-herb, Epilobium Hornemani, Rich.

Mountain Cud-weed, Gnaphatium supinum, Villars.

Rattlesnake-root, Prenanthes serpentarin, Pursh, rar. nenc, Gray.

Rattlesnake-root, Prenanthes Boottii, Gray.

Mountain - blueberry, Vaccinium caespitosim, Michx.

Bog Bilberry, Vaccinium utiginosum, L.

Bearberry, Arctostaphylos alpina, Spreng.

Cassiope, Cassiope liypmoides, Don.

Bryanthus, Bryanthus taxifolius, Gray.

Alpine Azalea, Loiseleuria procumbens, Dew.

Alpine rose-bay, Rhododendron Lapponicum, Trade.

Diapensia, Diapensia Lapponica, L.

Alpine Speedwell, Teronica alpina, L.

Alpine Painted Cup, Castilleia pallida, Kunth var. septentrionalis, Gray.

Butterwort, Pinguicula vulgaris, L.

Mountain Sorrel, Omyria digyna, Hill.

Dwarf Birch, Betula glandulosa, Michx.

Dwarf Willow, Salix phylicifolia, L.

Bearberry Willow, Salix Cicu-ursi, Pursh.

Herbaceous Willow, Salix herbucea, L.

Dwarf Willow, Saix argyrocumpa, Anders. 
Wood-rush, Luäula arcuceta, Meyer.

Wood-rush, Luzula spicata, Desvaux.

Sedge-rush, Carex capitata, L.

Sedge-rush, Carex atrata, L., var. ovata, Boott.

Sedge-rush, Carex vulgaris, Fries, vur. hyperborea, Boott.

Hair-grass, Deschampsia caespitose, Beaur.

Holy-grass, Hierochloc alpina, Roem and Schultes.

To these should be added a few sub-alpines, which the casual collector would not be likely to distinguish from alpines proper. These are:

Mountain Sand-wort, Arenaria Groentandica, Spreng.

Mountain Arena, Geum rudiatum, Michx., var. Peckii, Gray.

Cloud-berry, Rubus Chamremorus, L.

Alpine Golden-rod, Solidago Virgaurea, L., urer. Alpina, Bigel.

Amica, Amica Chamissonis, Less.

Cow-berry, Mountain Cranberry, Tacimium Vitis-Ircea, L.

Eye-bright, Euphrasia officinalis, L.

Alpine Knot-weed, Polygonum Tixipam, L.

Crowberry, Empetrum nigmum, L.

Mountain Orchis, Habenaria obtusata, Rich.

Mountain bulrush, Scirpus caespitosus, L.

Seilge, Carex capillaris, L.

Trisetum, Trisetum sub-spicatum, Beaur.

Any one comparing these lists with similar ones from Switzerland, the Pyrenees, or the Himalaya, or, indeed, any of the high ranges the north 
over, will note at once many marked correspondences. A large number of plants will be identical, while many others will exhibit close similarity. Yet are the peaks upon which they g'row separated by profound oceans or continental distances. What is the key to this wonderful distribution? The explanation given by Gray and others is that these boreal plants came south in the glacial period. When the climatic conditions, howerer, changed, they followed the retreat of the ice towards the north. Still, while the main army of plants, pursued by warmth, continued their march towards the pole, some found congenial conditions on the mountains, survived and perpetuated themselves. Thus we find them on isolated peaks, sojourning, as it were, in a strange land, and often accompanied by a peculiar local fauna, which, with them, reappears again far to the north.

Again, the collector will note that although the plants are small, they root deep, and often possess flowers of surpassing brilliancy of color. They are, too, apt to be large for the size of the plant. The dwarf azalea, the pretty diapensia, the mountain rhododendron, the moss-like cassiope, are surely among the loveliest of our wild flowers. A day spent in their collection is rubrical forever. 
AUGUST. 


\section{BLUE CLRLS.}

\section{(Trichostema.)}

The tint of the sky,

Has been given to you, In your laughing blue eye And your bonnet of blue, In the shade of your gown, In your dress, in your hair ; In your gems, in your crown, There is blue everywhere.

Was Blue Beard your father, My pretty Blue Curls?

They say he was rather

Too partial to girls.

What charm of his daughter Induced him to spare From general slaughter

Thy maidenhood fair?

Did he love your poor mother The dearest and best, Tho, for some whim or other, He sent to her rest?

Did he dote on your tresses, The hue of his beard ?

Did he seek your caresses, Or was he afeard?

However he ended, In sorrow or glee, No sin has descended From him upon thee;

No crimsoning stain

Of his scimitar wild, Shall ever remain

On his innocent child. 


\section{AUGUST.}

"Our children know each wild-wood smell,

The bayberry and the fern ;

The man who does not know them well

Is all too old to learn."

-Holmes.

A bouquet of August flowers has not the aspect of airy grace that distinguishes one gathered in earlier months. The colors are more intensified, and the whites are rarely tinged with rose. To make up for these qualities, they are more gorgeous. When tastefully arranged, they will vie with any hot-house farorites. They possibly require a little more repression, but with patience in the treatment, the resulting nosegay cannot be surpassed. Truly they are typical of the perfect year, mature but not yet declining. Only here and there a glowing goldenrod gives warning of the sorrowful Autumn.

How regal are these flowers in their splendor! We cannot paint in words, nor can art depict, the cardinal flower by its native stream. One sometimes surprises the whole sacred college proceeding to some conclave on high ecclesiastical rite. So gorgeous is their costume that it puts to shame all humbler plants. The car- 
dinals will form a bouquet by themselves. They are members of the genus Lobelia, and the finest of a race in which there are several beanties. The others, like Indian tobacco, have small blue flowers, and are found quite commonly in summer, in meadows and low grounds. They are all, in a measure, poisonous, but not to the touch. The name Lobelia was given in honor of the Flemish botanist, De l'Obel, so that when quacks speak of IIighbelia and Lor:belia, they perpetrate a rery tolerable joke.

We have said that the cardinals should be kept by themselves, but the pure and fragrant clethra, or sweet pepper bush, can, without a fear of injury, approach their aristocratic company. This handsome shrub begins to bloom in late July, but it lingers to greet the cardinals. Why should we turn to China, Japan, and the isles of the sea, when our own forests yield us such a shrub as this?

The "lilies of the field" are still with us in this month; at least, the Turk's-cap is still found in perfection. Their inimitable raiment is necessary to brighten our bouquet. To them as a basis we add the feathery white of thoroughwort, and dispose here and there an early golden-rod or aster.

But many of these plants are most natural in their own surroundings, and here we must learn to know them. They will, perhaps, put on airs when taken to the city, but here they are rery sociable. He knows but little of Nature who 
supposes that flowers are not susceptible of kindness; one may have

"MIany a life-long leafy friend."

Moreorer, they have their own friendships, predilections, and associations.

Look now for the pretty blue monkey flower and the closed or box-gentian. This latter is in no wise so beautiful as its cousin, the "fringed," but it has a shade of the same transcendent blue. Sometimes the color is almost metallic; again it will be a deep, opaque azure. These flowers are only nominally closed; the bee can pry them open. Near them generally grows the turtle-head, and a bouquet combining them with the cardinals is a thing of beauty. We thus have the red, white, and blue. These all grow by stream or river banks, or in wet meadows. The cardinal well bears transplanting, and is a great ornament to a garden. Here it has an odd trick of escaping from the rich bed into the gravel paths-a chance for a moral.

The star flowers of compositre grow more and more frequent and characteristic as the summer declines. Even thus early they are everywhere. In the swamp the iron-weed lights up its purple beacon; near it the thoroughworts, purple or white, are seen, and there are myriad thistles, hawkweeds and fire-weeds. The climbing thoroughwort, or mikania, clrapes the copses.

We never can pass the ererlastings, our American edelweiss, either the superb and pure 
immortelle, or the less handsome one which, by its ineffable odor, suggests some weird impression of a past life.

If we but touch it the strange perfume haunts for the rest of the day and the mind gropes into the boundless past for something it cannot recall. Dr. Holmes spoke of the peculiar effect that this odor has, and endearored to account for it. To some persons the smell is disagreeable; to us it is an antidote to Lethe.

A series of plants distinctive of August are the tick-trefoils. This common name is bestowed in reference to the fruits and leares. The former are a sort of pea-pod, clothed with minute hooks, and which breaks up at a touch into flat joints. Each detached piece adheres to the clothes like original sin. It does no good to attempt rubbing them off; only deliberate removal of each separate piece will alone suffice. This is a labor of time-and sometimes of love; never of patience. This plant, in brief, illustrates how man may be made an unwilling agent in plant distribution. There are a great many rarieties of these Desmodians, and when in flower, their pea-shaped blossoms are very light, delicate and pretty. The high bush-clovers are their cousins.

The great pea family furnishes several other showy Angust flowers, the loveleist of which, perhaps, is the ground-nut with its powerful but too evanescent fragrance of violets. The shell-like flowers are a purplish brown, and hare 
a peculiar twist in the heel. The wild indigoso conspicuous a yellow on many meadows, belongs to the same order, and is a stout, bushy herb. It is often attached by country people to the harness of horses to keep off flies, though it would appear to be of doubtful efficacy. Still we cannot say how much worse off the poor beasts might be without it. Then there is the beach-pea, which is not distinctively an August plant, but which still graces the sea-side with its trailing rines, and large, purple, showy flowers. We often enry it its cool position, where it ever breathes the fresh, salt odor of the ocean.

We ought next to speak of the Cassia, but it is hardly fair to poke fun at it while it is asleep. Asleep! Do plants, then, have a period of slumber? Yes, many of them do, and the Cassia is a striking example. If one obserres it towards night-fall, he will perceive it fold its little leaves in prayer and sink to rest with a child-like faith. In the morning it will spread them out again, as if in joy at awaking. There are many plants that thus indulge in a period of repose-if indeed they all do not. The locusts, peas, sorrels, and many other plants noticeably exhibit the phenomenon. The pondlily closes its petals in the evening, and any one who has a garden will recall innumerable examples. The evening primroses, on the contrary, pop open at twilight and are marvelous to see. We have two species, the biennial, 
which is very variable in the size of its lemonyellow flowers, and the pretty dwarf, found in moist places. The tall species is very common in sandy regions and along road-sides throughout New England. I find that many persons have never seen the rery striking phenomena of its opening. It is well worth a quiet half hour of observation.

All the member of the genus Gerardia are very showy. They are representative August flowers, often called fox-gloves, from the resemblance to the well-known European flower. Indieed, they belong to the same great figwort family. They live as parasites on the roots of other plants, but, at the same time, do a reasonable portion of work for themselves. They are not born sycophants and thieves like the dodder, which one finds coiled like copper wire around the stems of herbs and bushes. Bees are very fond of gerardias, especially the yellow species which have a powerful fragrance and produce much nectar. TVe have often watched them about the bell-like flowers, which, although invitingly open, they merely pierce at the bottom, and thus burglarize the nectar. Let us examine one of these showy blossoms. It has four stamens, two long and two short. These, together with the whole interior of the corolla, are clothed with soft wool. That may be called the lip, is marked on the inner side by two parallel rows of reddish dots. The plant is often three feet in height, and the leares and 
even the sepals are exquisitely cut. There are sereral yellow gerardias earlier in the season. They grow in open woods. The dainty purple species--lores moist spots along road-sides-or half-marshes. It is especially lovely near the shore. In the actual salt marshes it gives place to a fleshy leared kind. Inland again, we find a purple one whose flowers are raised on alternate stalks. In all the flowers are very deciduous.

Climbing orer bushes, or even high up in trees, from which it trails like some tropical rine, may be seen the clustered white flowers of the clematis, soon to be succeeded by the feathery fruit. Nothing can be more lovely than this "virgin's bower" as it tosses its random spray orer a wall or copse. Indeed the stonewalls are the natural trellises of New England.

Our ancestors, when they collected the stones from out the pastures and deroted them to the construction of substantial fences, of a truth builded better than they knew. Their immediate object was to clear the field of obstructions, and resthetic consiclerations, if cherished at all, were probably of secondary importance. No one, howerer, with a sense of beauty, and with common powers of observation, can have travelled in New England without invoking blessings on those rough old farmers, who, though purely practical, have conferred so tasteful a gift.

Near the coast these stone fences are often 
too light to be either picturesque or protective. One climbs them at the peril of life and limb. A bold dash is all that saves from destruction. A false step, and the wall descends with the scaler. Inland the walls assume the permanent and artistic aspect which we so much admire. A new stone wall, to be sure, is a lovely object, but then it is rarely seen. Nature claims the recent and the old as hers, and soon subdues with lichens the raw tints of the granite, and conceals all rectilinear outlines with her shrubbery and flowers. The wild plants and the bushes which the operations of husbandry have driven from the fields, retreat with confidence within the shadow of the walls, assured there of protection and a home. Who could deliberately denude a wall of this its ornamental clothing?

At this season these mural fences are particularly charming. The woodbine clings to them caressingly, its topmost tendrils eren turning as if loth to go; the blue flowers of the bittersweet look out from unexpected crannies, while its green and scarlet berries are ripening in the sunlight. Here the Roxbury waxwork scrambles orer the stones, and the clematis flings its garland. The hardhack and meadow-sweet draw up in lines as for a final stand, and early golden-rods, with wands of yellow, impart a saddened glory to the scene. The rich clusters of the barberry are gradually changing from orange to scarlet, and the white-topped aster is 
suggestive of the approaching galaxy of stars. The broad white cymes of the elder, in their season, yield to the fragrant clethra, or the still sweeter ground-nut. Of course, the regetation varies with the location of the wall. The drier region has, by preference, been described, as more familiar to the reader.

Truly, "stone walls do not a prison make;" to minds innocent and quiet they may, indeed, prove a hermitage. They are our American ruins, and we could ill spare them from the landscape. Already, in August, there are premonitions of Autumn. The golden-rods are brilliant in the meadows, and along the highways, waring their yellow plumes amidst the spikes of hardhack, the paint brushes of the thistles, and the feathery heads of thoroughwort. The asters, too, with which the gown of Autumn is to be bespangled, are worn as jewels by the matron Summer. She does not employ the azure stars as freely as her younger and fairer sister, but exhibits the same elegant taste in their clisplay. She lores, too, to wreathe her brow with clematis. She is unaware that she is old; she still coquettes with the scarlet cardinals, whose row of celibacy does not prevent flirtation; keeps company with the meadow-beauty, and perfumes her garments with the pond-lily.

The tupelo is now attired in glossy green and red. It is a small tree but at this season, one of the rery showiest. Then there are the sumacs; their elegant pinnate foliage is already 
blotched with crimson; while the poison-ivy is mottled with yellow and brown. The stems of the poke-weed are purpling in color, and its berries, so precions to the birds, are full to repletion with ruddy juice. Often some bright tinged leaf will float down to us from a maple, while in the elm trees we may see an entire branch of gold. It looks as if some Midas had touched it with his avaricious finger and transmuted the texture into metal.

Often as one strolls throngh the woods, he sees some brilliant tint, which he conceives to be an unfamiliar flower. It appears to be a prize hitherto unattained. Approaching the object, it is found to be, not the imagined flower, but a gaudy leaf.

Many of the seeds and pods are colored and add beauty to the scene. There are, too, the splendid pompons of sumac, the bright red clusters of the mountain-ash, the scarlet clusters of the bunch-berry, the deep blue globes of Clintonia, the ivory-white necklace of baneberry, the purple speckled fruit of Solomon'sseal (the false kind), and the coral clusters of Jack-in-the-pulpit. The priest has taken to his beads.

The close of the Summer must of necessity bring sad thoughts. It seems but a day since we saw the first timid anemone in April, and now the blue and gold of Autumn is at hand. So near are death and life, that even as we pluck a full dyed leaflet we may find at the end 
of the branch the tender opening buds, and often the promise of next year's flowers.

"Spring and Summer here dance hand in hand."

One of the most beautiful flowers of this month-or of any -is the Sabbatia, found about the borders of brackish ponds near the coast. It begins to flower in July and its blossoming period extends into September. It is a glory to behold, a member of the gentian family, which affords so many beauties. The nonbotanist might think he had found a beautiful pink composite; the radiate look of the flower suggests that family. This is due to the deepparted, rose red, or rarely white, corolla. It requires no floral education to admire these charming flowers.

\section{PLANTS OF THE SEA-SHORE.}

"Ye fresh flowers that brave

What Summer here escapes not, the fierce wave, And whole artillery of the western blast."

- Wordscorth.

One who resides for a while near the salt water will perceive that there are certain plants that love the vicinity of the sea. We are not now speaking of true maritime plants, but of those littoral species just above tide-water, or even washed by the ocean's ebb and flom. These, like other plants, vary with the season, and pass along in regular procession through- 
out the season. They are, however, most in evidence, in the late Summer. Abore the line of refuse sea-weed is the pretty beach-pea, with purple flowers and pinnate leaves. It forms large patches, and the full pods look really appetizing. A little further up from the shore the pink bind-weeds are in all their glory, twining over the shrubbery, and spreading their silken tents for wandering bees. Every where we see the Venus' looking-glass, looking like a bluebell, which, in effect, it really is. Then, too, he will notice the blue toad-flax, the purple gerardias, certain fleshy leaved asters, and the camphor-weed. Not in bloom but observable for its beautifully dissected foliage, is a salt-water wormwood. Its flowers are never very pretty. It is the cousin of the western sage bush.

In similar places grows the water pimpermel, and not far off is the charming "poor man's weather-glass," or true pimpernel. Both of these plants of the primrose family grow also in Europe. The first is interesting from the row of sterile filaments which throw light on the opposition of stamens in the family. In the second the flowers quickly close upon obscuration of the sun; hence the common name. It is a most lovely little flower, usually brick-red, occasionally blue. On the banks of salt rums or estuaries may be found quantities of silverweed, with pinnate leaves, and serrate leaflets, white and silky beneath, with smaller ones interspersed. The flowers are like those of the 
common cinque-fọil, but larger, and raised on long stalks. The plant grows by rumners.

Sereral of the Tmbelliferce are prevalent near the shore. One always finds the waterparsnip, with its pinnate leares and white umbels, and the small and delicate mock bishop'sweed. The dwarf erening primrose is common in the sands, but the queerest plant is the seasandwort, with its thick, fleshy leaves. Maritime plants, indeed, are apt to be thus succulent. So we find the samphires, the saltworts, and some of the pigweeds. Eren the gerardias and spurreys become so near the water, and the maritime golden-rod partakes of the same character.

Of course, near the shore there are a great number of characteristic sedges and grasses, rushes and the like. Sometimes we pick up that funny plant of the mustard family, the pennycress. It has broad, circular, wingerl pods, deeply notched at the top. The maritime grasses are some of them showy. At Block Island we have seen. a salt pond fringed with reed grass ten feet high. The sea-sand weed, a different plant, is sometimes used to bind the shifting sands, and thus prevent the incursions . of the sea. The hedge-hog or bur-grass is sometimes a nuisance to bathers. Gray calls it a vile weed.

Often we stop to study some particular plant, attracted by its intrinsic loveliness, or by some resemblance to another whose acquaintance we 
hare before made. Our humble weeds often throw a light on the structure of their proud relations. In other words, it does not do to ignore the peasantry in one's classification.

With tin box on shoulder we often wander by "the much-resounding sea," to pick up littoral plants. They have an especial charm. By the broken-down fences-and all fences are so broken in clam-bake regions, we find tall copses of wild sun-flowers. These are not so bold, aggressive and sancy-looking as those of the gardens, but still are very bright and showy. At Nerport we have found the garden "money" growing along the beach-the only coin that has ever turned up in our pathway. It is the pretty little loose-strife used in rases.

Besides the beach-pea, there is another leguminous plant very common, a species of bean, sprawling orer the sands and through the grasses. Tall spartinas are yet in flower. Just coming into bloom is the really splendid seaside golden-rod, and along the road is noticed fine clumps of the rich purple New England aster. The lance-leaved golden-rod covers the rolling hills with its yellow bloom. Often we find it thronged with that pretty moth, the Diopeia bella. In rery sandy stretches, a little inland, appears the heath-like knot weed, very delicate and pretty. It is more of a September plant. All visitors gather it into large bunches, as they do the marsh rosemary or sea-side larender, for winter decoration. 
Butterflies at times absolutely swarm orer the sands. They are those large burnt-sienna colored fellows, the Danais Archippus, creatures of exquisite beauty.

Sometimes we are tempted to chase the hermit crabs. What accommodating tenants they are, never taking possession of a house till the owners have parted with it forever-eren then backing in, as if apologizing! But then to think of being eternally saddled with one's real estate!

As we pick up some cast-off boot or some barnacle-incrusted timber, clothed with dulse, we always think of Ariel's lines:

"Nothing of him that doth fade,

But doth suffer a sea-change

Into something rich and strange."

How soon nature abrades our angles, polishes our surfaces, hides all ugly places, and smoothes the wrinkles of old mother earth! A chasm but yesterday-to-dlay behold a garden green with clinging ferns and bright with blossoms! Often we muse orer some pebble or shell, worn smooth by ages of washing. Whence did it come? How many changes has it seen? We fill our pockets with these trifles of the sea, but their glitter is for the strand alone.

"I fetch my sea-born treasures home;

But the poor, unsightly, noisome things

Have left their beauty on the shore,

With the sun, and the sand, and the wild uproar." 
In a collection of dried plants one from the sea-side always affects us like a beautiful poem, or a strain of solemn music, or the voice of a departed friend. The feeling is too "akin to tears." Yet who would forego these sacred moments? We are none the less brave for a moment's sadness. Says Henry Taylor:

"He that lacks time to mourn Lacks time to mend."

In the hurry and dash of life it is well if we can pause by the ocean, or think of it even, in silence and awe. We all have precious recollections of early days at the sea-side. These often sing in the mind like the murmur of marine shells. Te cannot recall where or when, but we know that sometime we were by the sea, and were young, and that others too were there who have drifted out across the even vaster ocean.

There is in life no gladder picture than that of little children on the beach. How infinite is their enjoyment! The wave-borne treasures of shell or weed have value above any of their after prizes. Hear their shouts and trills of delight_the music of little birds distinguished amidst the lash of waters! In one place a group of youthful Partingtons are trying with vain endeavor to turn back the Atlantic. They are undaunted by the incessant demolition of their handiwork. Again they write their names upon the sand for ocean to erase-a small work that, and an unworthy, for potent Neptune. He 
might, one would think, spare the autograph of a baby, he who has allowed ripple-marks and rain-drops to petrify into records of an ancient world. How much more imperishable should be the innocent touch of a child.

Behold those little waders yonder, letting the frothy waves dash round them, bowing down to catch the yeasty water, and rising, like Aphrodite, seaborn from the foam. Where the retreating tide leaves pools and shallow ponds among the rocks, there again we see young people eagerly luunting for marine wonders, the crimson dulse, the sea-wrack or the devils-apron. Here they find, perhaps beautiful flower-like animals - the composites of the sea, or transparent, vari-colored medusæ. The discovery of a shell or a hermit-crab, or a star-fish, is enough to produce a tumult of wildest joy. Up, beyond the beach slope billowy meadows-at this season gay with myriad flowers.

Yet, even now we have forebodings of the year's decline. It is still full Summer and the flowers are gorgeous, indeed the most splendid of the year, but they are the offspring of the mature season-and show no light frivolities of Spring.

It is not alone in vegetable life that we see or feel this advent of the Autumn. The birds do not sing as they did a month ago; some of them are heard only in the early morning or at twilight; others are utterly silent. It is a sad thought that they are ever to leave us, but- 
"'Tis always morning somewhere, And above the awakening continents, from shore to shore, sumewhere the birds are singing evermore."

Often now, as we look at the sky at sunset, we notice a green tint near the horizon. It is the cold, clear, infallible sign-manual of September. Let the sun glow as he may, he will not always be able to warm up that color. 
SEPTEMBER.

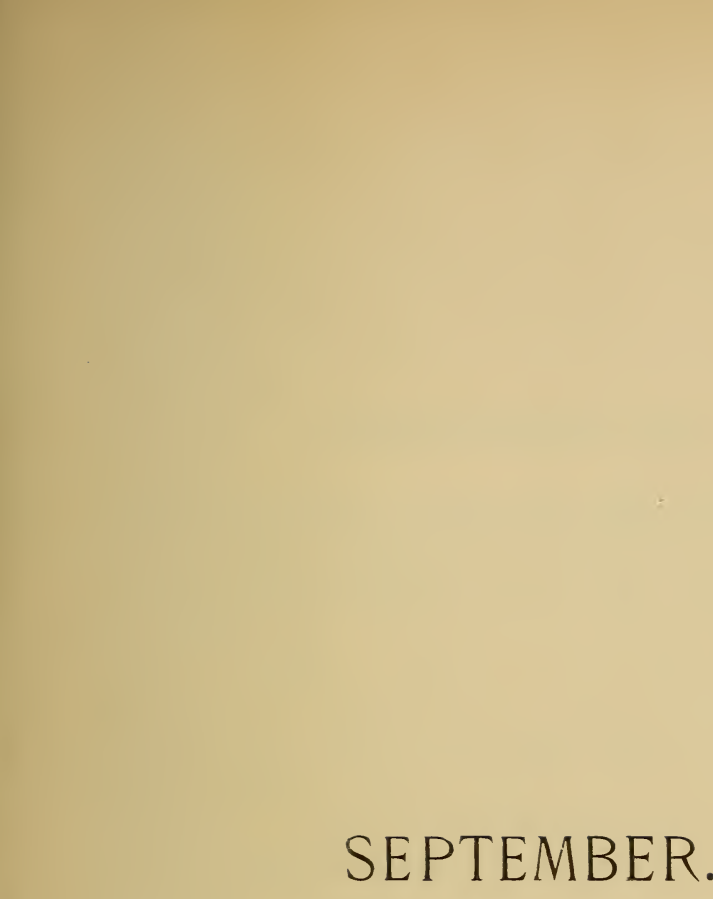




\section{THE CLOSED GENTIAN.}

Fair Gentian, come, thy secret to me tell, What dost thou hide within thy azure cell?

What sacred treasure keep from human view Beyond the curtains of thy blossom blue?

Are thy sweet eyes forever closed in sleep ?

Cannot thy lover take one little peep ? Or dost thou grant alone unto the bee To thus commune in silent thought with thee?

Some say thou art Pandora's box of old. That all the troubles of the world did hold; I wonder much, if underneath thy cope Remains as then, one fond and lingering hope!

The scarlet cardinal in his pomp and pride, His priestly terrors long in rain has tried, He cannot wrest confession of a sin, Nor hope thy trembling, gentle soul to win.

I think a sorrow, not a sin concealed, Thou wilt at last to tender pleading yield, And he will hear who learns thy secret then, A tale of love unknown to other men! 


\section{SEPTEMBER.}

"I love to wander through the woodlands hoary,

In the soft gloom of an autumnal dar,

When summer gathers up her robes of glory

And, like a dream of beauty, glides away."

- Sarah Helen Whitman.

It is a sad task to record the departure of the flowers. If anyone should visit the woods, however, in early September, he would scarcely imagine the summer on the decline. The woods teem with blossoms. True; but it is not for long. They are gathering for a final display, which, though it will be gorgeous and spectacular, will also be brief. Into this show not only the flowers, but the leaves even will be pressed. Te will still find a few of the brilliant August flowers, as the bright yellow bells of the gerardias, or the scarlet streamers of the cardinal flower, perhaps the white turtle-head, and the box or closed gentian.

Now is the time to study asters and goldenrods; their name is legion. We will consider golden-rods first, for though typical Autumn flowers, some begin to bloom as early as July. It is common to hear persons, ignorant of botany, say "the golden-rod," showing that they are totally unaware that there is more than one 
kind. So, when some one remarks that the golden-rod should be our national flower, we wonder which he has in mind. Is it the white one, or the maritime, or the broad-leared, or the strict? They are quite unlike in foliage, arrangement of flower clusters, and size of heads. The prevalent kind depends wholly on the location. One species, as splendid as any, is found on the tops of mountains only; another prevails on sandy plains; another on foot-hills; another by the sea, and still another in copses or eren woods. In some districts, indeed, it would be impossible to say that any one species was more common than another. Often a great variety grow mingled together. As soon as one's attention is directed to this diversity, the slightest scrutiny will show how various are the species.

These plants all belong to the great composite family, which includes the daisies, sunflowers, chickory, and dandelion. The genus Solidago of Linneus consists of plants herbaceous, indeed, but perennial, and often forming stout, almost woody stems. The stem-leares are nearly sessile, or without stalks, while the radical or lower ones are often long petioled and quite different in shape. The heads or flowerclusters vary much in the size and number of contained blossoms. These are, as in the daisy, of two kinds, tubular ones in the centre and rays around the margin. They are, in other words, like an aggregation of little daisies.

One of the earliest to appear is Solidago $a r^{2}-$ 
gutu. Almost simultaneously appears in woodlands the sweet golden-rod, with an anisate or. liquorice smell to the crushed foliage. One usually finds it thronged with wasps and blister beetles. A little later Solidago nemoralis begins to appear in pasture lands, a rather low species usually, with the wand of flowers turned to one side. Others then rapidly follow, until finally the whole landscape is aglow with their gorgeous yellow. A number of tall species especially love to grow along stone walls, which they do much to beautify. Among the late-flowering species is Solidago ccesia, with flower heads in the axils of the leaves on long bending stems. In similar places, rather more hilly, grows the broad-leaved golden-rod, also with axillary flowers. The splendid Solidago speciosa, and the almost equally handsome, rigid-leaved golden-rod, grow within our limits. One species, as has been mentioned, is white; at least, the rays are whitish, while the disk flowers are yellow. The result is a cream color.

The asters within our range are equally numerous. Their blue or white stars peep from every thicket. Sometimes large and showy heads of blossoms, worthy the attention of the gardener, entice the passerby with rays of lapis lazuli; and again a bushy species, almost leafless in appearance, will be white with radiant stars. It is hard to tell which species is the most beautiful, but we are inclined to award the palm to the New England aster par excellence. 
It is very tall, and when in full bloom shows a solid mass of royal purple flowers. It does well in cultivation, spreading to an amazing extent. Almost equally beautiful is the smooth, deep blue Aster lavis. Very various are the locations in which asters are found. Many prefer the dusty sides of roads or sandy plains. Others will be seen in deep woods only. Some will grow in copses, others near the coast, and two species actually in salt marshes.

There is something about the time at which these flowers bloom-the clear, cool September days, when the sky is washed out clean, and its blue incomparable; when the air at night is mildly frosty, and the blood is tingling with accelerated life, that rnakes one love them dearly. Each year they seem more beautiful.

Other very showy composites at this season are bur-marigolds of the swamps. Often we have seen a marsh aglow with them, much as in Spring it may be with the caltha. The rays are an inch long, making a splendid star. The rare rose-flowered coreopsis lingers also into September, and we have sunflowers innumerable.

The fringed gentian claims the most perfect days of all the year; those days when it is enough to breathe the air, and to revel in the beauty of creation; dreamy days, full of peace and blissful sadness.

There are those that fancy this is like the boxgentian, and never unfolds its silken lashes. 
Believe them not; its "sweet and quiet eye" is too pure and holy and faith-giving to be hidden always from poor doubting man. Bryant was a true lover of this beauty, and sings her story so sweetly that it always seems a sin to add one word of praise. He knows the very time to find it; the gentian atmosphere is breathed throughout his poem. On such a day, the first of September, 1895, we climbed a hill in Conway, Mass., and half way up found one sunny blossom of the gentian. How exquisite it seemed, well as we had known it always! It made a redletter day.

We speak of the blue fringed gentian, but it is not blue but violet-purple. If we place it besicle the gems of the forget-me-not we can sée a contrast, yet even these are not pure blue.

Another plant that grows with the Autumn beauty is the sweet-scented maiden's-tresses, an orchicl with cream-colored flowers arranged spirally on a straight, erect stem. In making a bouquet we should never forget these loring relations.

"Thou waitest late and comest alone," sings the poet, but he only means that the gentian survives after almost all the other flowers have departed; not that it is alone when it first opens in September. There is, perhaps, no time in the year when the forests and meads are more profusely adorned with flowers. Three weeks ago the woods were comparatively sombre, the roadsides and river-banks dusty and colorless. 
Suddenly Nature touches some hidden spring and all things burst forth in triumph.

The gentian days, the "dies gentiance," hare indeed arrived. The poison-ivy is flinging her gorgeous banners of orange and yellow from the "outward wall," to welcome her sovereign Autumn; the woodbine, clad in scarlet, climbs up the loftiest trees to have a look; the red maple lights up his signal fires, and the sumac unfurls her royal ensign. The blushing pokeweed comes with clusters of purple berries as an offering; the clematis presents its feathery garlands; and the grasses, those gallant spearmen, bow their heads as the princess passes by. Each tree has a color of its own. The suppliant birch is bedight with yellow; the trembling aspen still wears the green; the cornel is robed in mourning, and the oaks begin to don the russet. The sassafras is in motley raiment, "the only wear," and the leares are of many shapes and colors. The blue-berries are in claret costume, and will make it do good service till the middle of Norember. The hickories incline to yellow; they wear a burnished armor of their own. A hickory in full color is a sight worth seeing. Stand at the foot of one of these sinewy trees and gaze up into the golden tent abore you, and you will feel gradually suffused with the glow, as if you had partaken of some rare and mellow wine. The ferms, before they wither, assume rich umber tints and are glorious in color. Some of them bleach out white, and 
are then like the ghosts of leaves. If we add to our list the coral beads of Jack-in-the-pulpit, who has gone orer to the old church; the red ear-drops of the barberry, and the luscious amethystine globes of the grape, we will have mentioned only a few of the attractions of September.

A beautiful flower of these late days is the grass of Parnassus. It belongs to the saxifrage family, but has an anemone-like appearance. Its solitary white flowers, prettily streaked with green, are borne on scape-like stems, from the midst of a group of roundish heart-shaped, thick leaves. There are five true stamens, and at the base of each of the fire petals a group of peculiar, gland-tipped filaments. These are said to be deceptive organs, alluring insects to a Barmecide feast. 

OCTOBER. 


\section{MAPLES.}

Like Grecian hero of the ancient days, I silent stand in wonder and amaze, Within October's dreamy veil of haze.

While round me leaves are falling everywhere, With gentle motion through the ambient air, Their gold seems sifted into something rare.

The far-famed garden of Hesperides Showed nothing fairer to old Hercules, Than yonder golden glory of the trees.

Nor yet would Jason and his comrades bold Have sought in Colchis for the fleece of gold, Had they but known the prize our maples hold. 


\section{OCTOBER.}

"Who can paint like Nature? Can imagination boast Amid its gay creation, hues like hers?"

-Thomson.

The October atmosphere possesses an indescribable softness, and the sky a rich full blue peculiar to the season. Asters are now beyond their prime-but still rery beautiful as they linger by copse and path-way. From now till the middle of Norember there are colors in the forest to delight an artist's eye. We do not speak so much of the gorgeous tints of maple, sumac, and birch, as of those shades of umber, of brown, and purple which grow fairer every day.

The asters, we have said, are nearly gone. So are the golden-rods, their loved companions. Still, we find a few of both in thickets or on road-sides. The beautiful wavy-leafed aster lingers late, and so does the axile flowered golden-rod, with its pretty yellow flowers in the axils of the leaves.

Nuch has been written of the fringed gentian but not too much. It is one of the few flowers that have their niche in American poetry. Many remain to be enshrined till our natives become 
as familiar in one sense as is the primrose, the violet, and the daisy, in the ballad literature of England. The gentian is ever new and ever beautiful ; fresh, cool, delicate, loving, and withal most lovable. It is one of those flower's which seem to possess a soul, a something responsive to our human sympathy. It knows very well how much sadness there is in this life of ours, but its counsel is ever hopeful and cheery. Te feel in looking at it, that better days will come, if not here, at least in some dim-discovered future.

Sometimes a bee will plunge into the corolla, head foremost, maybe intoxicated by the nectar. It is pretty to see the soft fringed lids close round him.

The ferns, though somewhat past their glory, are very lovely still. The Dicksonias are especially elegant in green and gold. Their tracery is beyond all expression delicate. They often fade out white, when they are exceedingly dream-like and beautiful. Occasionally one will be found half green and half yellow ; Summer and Autumn side by side.

As we stroll by the bank of some rivulet, under over-arching birches, the sunlight is sifted through the golden leaves. It falls upon us in trembling gleams and shadows. Our eyes follow the narrow pathway winding up the hill and lost in mysterious foliage. So like is the scene to some Tennysonian word picture, that we almost expect to see Sir Launcelot or 
Sir Galahad in silver mail, descend the way on horseback. We note the sunlight glance from the armor; we observe the tossing of the knightly plume. The weird excrescences upon the oak-trees, gnarled and grim, seem like goblins which this chivalry is to conquer. It is difficult to believe that there has not been a combat here, for we find the maple leaves bespattered as with blood. The crimsoned foliage is the relic of the conflict.

Again, we imagine an older time and a fairer land and drift into the hazy realm of mythology. The odor of "life-ever-lasting" will at once produce a subtle transmigration.

Te have seen a picture-book unreal in its wealth of color, yet Nature is more extravagant than any painter. We once witnessed an October pageant in the woods of northern Vermont, which surpassed the wildest artist's dream. Nature spares no color; she is lavish with the palate. Sometimes neglecting the rest of the picture, she will throw one tree into high relief, and paint it in some gaudy dye. She makes the very water, reflecting the forest, to glow with brilliant colors. Not only are the leares suberb in color, but their shapes are infinite and their texture raried. Beauty and grace of attire are added to delicacy of hue. The sumacs hang out their leaflets in rows like the trophy banners in St. George's Chapel. See that hickory clothed in yellow, that beech in richest brown, that ash in olive green or umber, 
that cornel in maroon, that chestnut in gold! Every tree has a color of its own, and the air itself seems to inbibe the sum of all, until we feel as if we were breathing color. Let the dwellers in the tropics boast as they may of gorgeous flowers, of palms and ferns, and orchids, we would rather have one hour of our American Autumn than "a cycle of Cathay."

The leaves are falling one by one, The clematis has nearly spun Her feathery cap, and golden ferns Are seen where'er the woodsman turns.

"Tis pleasant now, " in good green wood," Where, like some errant Robin Hood, We wander, walking all day long, Or wake the forest glades with song.

Upon the stream in silence floats $\Lambda$ leafy fleet of fairy boats, Aud far above, in azure sky, The clouds, like ships, are sailing by.

As the month advances Nature throws her beautiful patterns upon the ground. We hesitate to tread upon anything so beautiful, but she does not raise her hand to save them. She knows that her fancy can reproduce what is of necessity destroyed. With the scissors she can use so well she will clip out new leaves for the coming season, and each tree shall resume its favorite outline. Indeed, even now, in the little buds that are packed away so nicely with overlapping scales and waterproof varnish, we can 
detect the forms of next year's foliage. A charming carpet is spread for us, but its tints are fleeting and its texture delicate. Some of the trees are quite bare, while at their feet still lie their golden summer garments.

Even at this late season there are beautiful colors surviving in the forest. One can gather a whole handful of lingering flowers. The fair, fringed gentian continues throughout the month; an occasional golden-rod gleams brightly amidst the low bushes, and a blue aster, like some lost pleiad, twinkles from amidst the fallen leaves. By the river bank are a few blossoms. of evening primrose surmounting a long stem of pods. Certain common Spring weeds, too, have a second period of flowering. The yarrow particularly rejoices in spreading out its white clusters to the sun, and seems oblivious of coming frosts. The little self-heal may also frequently be found, and the Autumn dandelion, true to its name at this season, if at no other, bespangles the green grass. This plant has a peculiar fancy for lingering about old college buildings, as if it were an alumnus revisiting its loved alma mater. The May-weed is still in flower, and even an ox-eye daisy may be found. The charming forget-me-not still utters its plaintive entreaty, with a tear-drop in its eye of blue. From earliest Spring till the latest days of Autumn this pretty flower offers us its azure gems.

A true Autumn flower, perhaps the very last, 
is the witch-hazel, whose singular yellow blossoms attract attention in the woods. It grows along streams, and is a bush of varying size. The flowers have a spider-like appearance, and the fruit which matures next year explocles with the noise of a little pistol, scattering the shining seeds. This is the plant which the gold-diggers and water-seekers used as a divining rod, and which certain credulous persons still believe in. As the plant which dares to stand at the foot of the class, as it were, and blossom last, it is interesting.

The poke-weed, loved of Thoreau, is at this season one of our handsomest plants. Its pendant clusters of purple berries, threaded together by a stem of crimson, are still seen beside the roads. Often, the whole stem system of the plant will be ruddy. It is certainly regal in its aspect.

In the last days of the month, and when most of the leares have fallen, one can still collect from those that remain a beautiful bouquet. Many of the oaks retain their splendid colors, which, like the windows of cathedrals, should be seen when translucent with the declining sun-light. Indeed, in looking at them, the feeling of reverence is inspired, and the "longdrawn aisle" recallecl.

The bay-berry is still green and fragrant; the laurel's glossy verdure is on hand for Christmas; a belated maple shows us an exquisite silhouette in red and yellow; the aspen shakes in our faces its tantalizing golden dollais; the 
hickory glows with a promise of future backlog's and nuts; the wrecked sumacs fly their signals of distress, and the huckleberries stud the billowy meadows with islands of ruddy beanty. Long after all else is faded, one finds the bright, glossy leares of the green brier, and the claret-colored vines of dewberry.

The approach of Winter is by most persons hailed with dread. When we see the leares falling from the trees, or lying dead and trampled on the side-walks, it is hard to believe that verdure can ever return; that there will again be fresh leaves and flowers. Autumn, even in its rare, beautiful aspects, is sad. There is an indefinable something in the air, in the very col.ors we admire, that makes us more or less despondent. Winter itself is not so depressing as late Autumn.

When the snow has once arrived and the mercury sinks to its winter mean, we are prepared for the worst, and consequently enjoy every respite that Nature affords. At present, in October, we are still looking for Indian summer and other delusive pleasures that may or may not come; we do not accept things as they are. Still, if we have eyes to see it, there is much beauty in these late Autumnal days. The morning mist that hangs over lake and river, the smoke curling up from the villages, the brown meadows-all offer incomparable attractions. The vivid hues of the earlier season are not so grateful to the eye as the rich clarets and 10 
browns, the maroons and ambers, and neutral tints of these later days.

But even now we have brilliant colors. Some of the oaks are positively glorious, a few maples yet retain their golden foliage; and the huckleberry bushes in the pastures seem to burn and glow with color. We love to walk through the fallen leares and inhale their invigorating odor. How thickly they mantle the forest streams! How endless are their patterns! Infinite as is the variety of flowers, they do not present the diversity exhibited by leaves. Here Nature seems to have revelled in her resources.

Give us, said some one, two Junes and two Octobers, and we will gladly dispense with August. Certainly these still, dreamy days are a benison. The most prosaic man now becomes thoughtful. He revolves rhymes and thinks out poems. He is a child again, with a child's dreams and fantasies. As these, though wild, are pure and innocent, we cannot condemn the visionary. Who can say where the dream ends and reality begins? 

NOVEMBER.

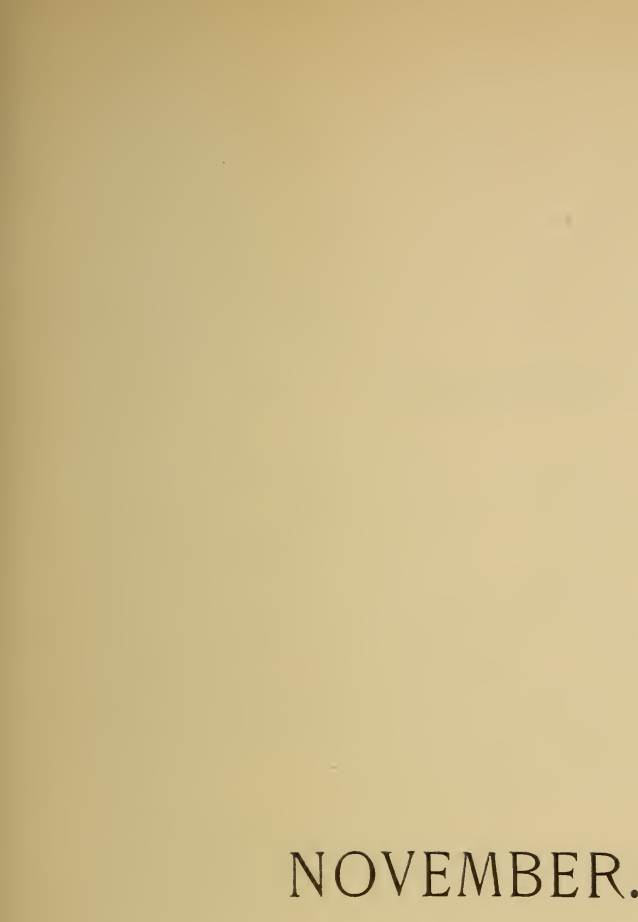
Noven

Cang 


\section{THE LAST LEAF.}

I've bathed in April showers;

I've welcomed summer showcrs; I've blushed in autumn sun, To think of all I've done.

But now my days are o'er, I'll never whisper more My story in the breeze, To all the listening trees.

I end my trembling quest; I've gained the promised rest.-At peace with all to lie, Thou sad old world, good-bye! 


\section{NOVEMBER.}

"O shadow sister of summer!

Astray from the world of dreams, Thou wraith of the bloom departed,

Thou echo of spring-tide streams, Thou moon-light and star-light vision

Of a day that will come no more, Would that our love might win thee

To dwell on this stormy shore!"

-Frances L. Mace.

We often think that trees are as beautiful in their undraped condition as when clothed with foliage. Each has its peculiarity of branching and makes its own silhonette against the sky. I doff my hat to some old elm whose quaint branches twist and turn like the locks of a mighty gorgon. It is ever beautiful-now when the limbs are bare; in Spring when the brown buds cover it, and in Summer when it is piled high witls green. Note the magnificent buttresses of the trunk.

How characteristic, by the way, are the boles of trees, each as individual as a human face. Take the ridged and mossy elm; the clean, gray, mottled beech; the chestnut, smooth and polished when young; long-scored when old; the iron-wood, with its tense muscles standing out like those of a wrestler; the ash, with its 
close intricacy of creases and ridges; the hickory, with tough, resistant columns, and the snow-white shaft of the lady-birch.

Consider the various buds. How marvellous is their provision for protection! Here are, for instance, those of the horse-chestnut, varnished without, and within packed with soft, warm wool. The hickory has almost coriaceous scales; a neat bundle in all cases. Then see the infinite variety of shapes, from the long pointed bud of the beech to the insignificant ones of the ash, or the green and prominent ones of the lilac. From these buds we can learn the future manner of branching, as also the position of leares. The crescentic stars beneath the buds show where the foliage once stood. If then, the buds are now opposite, so were, and will be, the leaves.

The fall of the leaf is a curious matter. Early in the season in many plants, trees especially, there begins to be formed a line of separation between leaf-stalk and parent-stem. This, as the season advances, grows deeper, until finally the attachment is only nominal. Then mere gravity, the disturbance by wind or rain is enough to detach the leaf. If frost should occur, a layer of ice is formed at this incision, and all the leaves fall, as we often see in the horse chestnut, as if by word of command. The piles of fallen leaves are themselves interesting. Fresh, glossy, sweet smelling at first, they soon become dry and wrinkled. Thoreau has aptly compared some dried leaves to the tin and iron cuttings 
around a foundry. The likeness is often very marked.

How infinite are the forms of these fallen leaves! Nature, in fashioning them, indulges in the wildest vagaries and fancies. It is interesting to pick up some clean, well-marked leaf, like that of the tulip tree or a magnolia, or the sugar maple, and study its marvellous veining. See how, in many cases, the margin is reinforced to prevent lashing by the wind. This is done by means of arches and counter-arches. A skillful architect is here.

Even now the roods are not devoid of green. Besides the pines, junipers, hemlock and spruce, we find the mountain laurel, the rose-bay, and the holly, holding their leaves. Many herbaceous plants, too, are evergreen, like the prince's pine, and then we have the lovely forms of clubmoss, and the true mosses.

Craunch! sounds the earth, as each reckless footstep maybe demolishes a palace. Jack Frost has been busy under ground.

" No hammers fell, no ponderous axes rung, Like some tall palm the mystic fabric sprung."

The edifice arose silently in the night, the icecolumns raising the soil above them, and revealing halls which Aladdin might have covetted. The architect does not confine himself to Corinthian, Doric, or any established human style, but evolves a principle of his own, which for beauty and unity is unequalled by any effort 
of man. Nor has he been idle above ground, for we find each faded flower, each blade of grass, transfigured by his touch and gleaming with iridescent facets. Where the spider has thrown his silken cable from one object to another the busy spirit has hung his icy lanterns gay with rainbow colors. He has laid his hand upon the ferns, and their lace work spangles with diamonds; upon the mosses, and a steelclad army of spearmen arises. Not yet desirous of bridging larger streams, he is content to span the rivulets; nor does he yet trace upon our window-panes the marvellous patterns we in winter admire. His present work is merely to idealize, and in this he is successful, for naught escapes his beautifying touch.

These later days of Autumn are indeed delightful. In early morning, wrapped in warm apparel, we dash along the meadows, breathing the delicious air. It tastes as fresh and invigorating as ice-water in August, and we have three times the force we then had. Indeed, we are prepared to lead a storming party or to write an epic. With such joyous spirit tingling in our veins there is nothing beyond our power. Later in the day the warm sunlight canses us to remove our extra garments, and beams upon us with a genial influence unfelt at any other season. This is not the time to seek the shrub, so, basking under the southern exposure of the house, we watch the wasps as they lazily attempt to climb the windows, and, Sisyphus-like, 
fall back, only to attempt the futile task once more. The old cat, cosily purring away the hours, half-opens an eye as some belated butterfly flits to a lingering aster, or a painted leaflet drops silently by her side. The "sound of dropping nuts is heard, though all the woods are still," and merry children troop to the forest to gather treasure. Surely some of our happiest recollections are associated with nut-gathering. How beautiful often are the nuts themselves, and how neatly packed away in velret caskets armed without with spines:

Sometime in Norember, authorities differ as to the date, comes a period known as Indian summer. We like to think it is what the Acadians called "the summer of all Saints," which would locate it in the early part of the month. Whenever it comes, and it is variable, and sometimes comes not at all, we all know it. In the morning there is a mist, which later lingers as a delicious haze, toning down the outlines of familiar objects, and rendering them strange and dream-like. These mists sometimes produce a sort of mirage and show us objects which, in reality, do not exist. Nature gets up a little smoke, as it were, to hide her transformation scenes.

The brown slopes of the hills are now empurpled by the wild indigo. They wear a sort of ecclesiastical mourning tint. The clumps of bay-berries too, are of a bronzy color, while the fruit itself is a beautiful whitish gray. The de- 
licious aroma of these berries is a true wood odor, full of charming suggestions.

We come to a beautiful grove in a hollow. It is now denuded of its foliage and wears a subdued gray tint; beyond this is another wood of oak, still in its ruddy color. In the distance the blue of the sky, where filmy clouds are sleeping, is mingled with the drowsy haze of the earth.

A curious effect is given to the leares at this time by their upturned edges, which reveal the glaucous surface of the under sides. The water of the little pond sparkles like a gem.

As we saunter we pick up the belated odds and ends of flowers or fruit; here the tip of an aster still holding its azure star; there a white yarrow, in its name recalling sweet ballads of our home over the great water. We pluck large masses of rose-hips now dyed and polished, and as brilliant as a necklace of rubies. It is a proper fruit to follow the delicate, hearen-scented flowers of June.

"O'er the earth there comes a bloom;

Sunny light for sullen gloom,

Warm perfume for vapor cold-

I smell the rose above the mould."

To our bouquet we now add the half-opened pods of milk-weed, revealing the floss within; the gray fruit of the bay-berry, the red of holly, and the downy pappus of hawk-weed and wild lettuce. By the marsh we find the tassels of alder and hazel well developed. 
"Spring aud Summer here dance hand in hand."

We can hardly realize that these are to be the flowers of another season-the pretty swinging pendants of showery April. It is interesting too, to note how large and seemingly far adranced are next year's buds. During the Summer the leares have concealed them, but now they are very prominent, especially upon the white azalea.

We stop to gather a few wreaths of "creeping-jenny" and spires of ground-pine, and walk on towards the river. Surely no more beautiful time ever existed. It is All Saints Day, and we think the blessed are with us for there is a sweet calm in accord with their actual presence. We feel it and are glad in it. May it come to all who are weary and sorrow-laclen!

The shadows on the river are beautiful beyond description. The inrerted moods are colored nearly like those they reflect. The whole view is like a picture, one by some master hand, a poet as $\pi$ ell as painter.

"Filled is the air with a dreamy and magical light ;

And the landscape

Lies as if new created in all the freshness of childhood."

We pause to rest upon an old stump, and marrel long and deep. Oh, that we could see beyond the veil of mist, so light, so beautiful, yet so impenetrable!

The Polaris expedition brought back from 
$80^{\circ}$ north a dandelion found in full bloom. Flowering plants of Alpine habits thrive in Spitzbergen and Nova Zembla, and our own little chick-weed blooms with us even in winter. Hence there is no need to be surprised at any exhibition of vital tenacity in the plant world. We see most charming flowers blooming by the sides of glaciers or near to the perpetual snow, and in such places they do not seem unnatural; yet when we glean here our aftermath of yarrow and groundsel we remark upon it as strange. The May-weed, a facetious misnomer, blooms on still, and so does a stray carrot and the bouncing bet. We cherish every blossom that thus lingers on the threshold of Winter. 
WINTER. 
My tree stands clothed in panoply of ice, Abore her head a single radiant star;

Her raiment sparkles with each rare device;

With diamonds, pearls, and rubies from afar.

Gleams as of opal from her branches glow, And many tinkles as of little bells, Fill all the air with sweet melodious flow, Like distant chimes in whispering farewells.

The sturdy boughs now surge with every breeze, With fairy grandeur startling my fixed gaze, My eye each moment does some beauty seize, The changing light some rarer gem displays.

$\mathrm{O}$, can I not this crystal marvel keep, Surpassing far Aladdin's famous hall?

A vision as of one in hasheesh sleep. Who sees new glories rising to his call?

Let not this wealth transcendent disappear,

O magic genius, stay thy ruthless will! Grant that this crowning glory of the year

Unchanged remain to charm my senses still! 


\section{WINTER.}

"Winter, thou ruler of the inverted year."

-Thomson.

Winter is, with us, a favorite season. To be sure we do not now have the green fields, the leafy woods, the flowers and the life of Summer, but there is much that compensates for all these. In Summer the home circle is apt to be broken; our friends leare the city, and we feel like a pilgrim ourselves, liable to move on. Then too, we are subjected to the plague of flies and mosquitoes. But in winter we have the fireside pleasures which none other on earth can equal. Happy is the man who, after his day of toil, is sure of finding a welcome from glad faces, and the sweet voice of children to cheer his leisure hours!

Winter, viewed in some respects, is certainly objectionable. One especially objects to the curtailment of his walks. It requires sometimes good courage to walk up and down the slippery hills. The penitential ashes may be strewed in rain. Then, on other days, we are prevented from seeking the exercise which prudence demands by the depth of the snow, or its sherbetlike condition. There is not much delight in 
wading to one's knees in snow-water. Again, the mercury sinks to the wee small figures of Fahrenheit's scale, and we shudder with the cold.

At such times we extemporize a walk and pace up and down our apartments like a second prisoner of Chillon, repeating odds and ends of poetry-from Watts Hymns to the Idylls of the King.

It is by no means impossible, however, to enjoy a good walk in winter. Some of the pleasantest we recall were taken in that season. All that is necessary to comfort is secure footing, warm clothing, and congenial companionship. If the air is sufficiently ozonized, we dash along in fine style, plunging through snow sliding over gutters, climbing fences at a bound. If it is snowing and blowing, all the better. The storm imparts a healthy tingle to the cheeks.

We meet friends who nod us a hasty recognition and are out of sight in a moment. Now we meet fewer and fewer persons; the billowy snow is marked by only occasional footsteps, and finally we have an unexplored field before us, and the foliage of the sombre pines. Under the trees that are sighing in the wind we try to find our summer sanctum, but all in vain; there is nothing recognizable. Winter is a great transmuter and magician. It is difficult to believe that under this fleecy counterpane the violets are quietly sleeping, and will rise at the 
trumpet-call of spring. To test our faith in this life to come, we snap a twig of maple and find it green and juicy. In a few months more its buds will burst their casements and blossom into beauty.

Nature to be won, must be wooed, and that, too, in all her many humors. It will not do to risit her only when she smiles, but we must view her when her company manners are put aside for her own ease. The heart that truly seeks heralways finds. She does not tell all she knows; that would be folly. But she does confide very much in her familiar moments. To know all her graces, we must court her in storms as well as in sunshine, and study the blossoms of the frost as we would the blossoms of the field. True, such a pursuit is attended by discomforts, yet no weather is so bad as it looks. We hare encountered nearly all the moods of very variable winters. When she smiles, we must be merry with her; when she weeps, we must be present to console. I think, sometimes, that we love her best when she storms, seizing the great oaks by their tops and whirling them about, or blowing the fallen leaves in stormy mazurkas.

After a slight snow-fall, we seek the woods. A pretty stream, an Undine-chen, meanders through the valley, not frozen over, but merely bounded by a fringe of ice. It sings some pleasant story of the summer violets; the words escape us, but the music lingers still. Occasionally the rivulet dimples all over with 
smiles, or will even laugh with a ripple of glee. On the still pools are sailing leaf-gondolas of curious pattern. They seem to have no particular port in view, but if they are steered by invisible sprites, the little fellows do not care to land. Perhaps the touching of mother earth would reveal them. Sometimes an eddy will catch the skiffs and whirl them about in a manner to make their possible passengers unhappy. Doubtless they are provided with a panacea against the evils of the deep.

Great fern feathers, unwithered by the frost, at intervals droop over the brook. The trees interlace their branches orerhead, and sing a wild accompaniment to the music of the water. Some of them are hoary fellows, with beards of gray lichen tufting their chins, and some have graceful vine-companions that hang lovingly about them. The oaks still hold their brown mementoes of summer, a pretty back-ground to a winter picture.

All life appears to require periods of rest. There must be a quiescent time for all created things to recuperate their forces. In our climate winter, and in the tropics the dry season, offer such opportunities. Quiet as our trees and smaller plants now are, they are in fact surcharged with abundant life. The warm sunlight only is required, together with the tepid rains of spring to reclothe them with green. Indeed there is more active life going on among plants in winter than any one at first suspects. 
Now is the time when bulbs, root-stocks and certain other subterranean forms of stem, are either putting in their good work, or preparing therefor. Upturn any mass of leaves in a favorable spot in the woods, and there will be revealed a lot of vigorous, aggressive looking buds, ready for the spring contest. For all plant life, like that of animals, is a battle, the more vigorous or the better endowed ultimately crowding out the weaker or less well provided. It is not always mere strength that conquers, but neat adaption or careful foresight, if we may so speak, in taking advantage of errors on the part of the enemy. Every plant must be alert, on guard, lest the foe surprise it.

Among the most obvious aspects of winter life among plants, is the appearance of the leafless trees. Each one has a character of its own. One old elm writhes and twists his giant limbs like some huge hydra; the graceful poplars tower straight and tall, every branch aspiring; the oaks are examples of sturdy resistance; the hickories of Yankee subtlety and pliant strength. How beautiful and yet how different are the twigs or sprays of all these!

The trunk of the elm dissolves into finer and finer branchlets; the fir maintains a straight spire clothed with its sombre green; the tupelo shows a zigzag, free and easy, but characteristic branching; the honey-locust a most beautiful silhouette of interlacing lines. Even the trunks of trees have a peculiarity of their own that 
every woodman knows. The beech possesses a smooth bark curiously mottled; the white birch, as its name implies, a snowy surface that makes it a feature in the landscape, and the ash has a close ridged, well marked bole, while the ironwood shows the tense sinews of an athlete. So characteristic are these features of the bark that one learns to infallibly know his tree and often its specie and rariety by the clothes it wears. Of course it is in winter that such points are best seen.

It is interesting to study the wrecks of the previous summer; to see how many plants one can recognize by the debris. Many a pathetic ruin, beautiful even in decay, shows where a living plant once stood. See the miniature birds nest formed by the wild carrot. Frosted with ice it is indeed exquisite. How elegant are those prickly pods of thorn-apple! Decorative artists long ago discovered their value in design. The long, four-valved pods of evening primrose linger into winter; the wild pinks and bouncing-bet show pretty urns or chalices, while burs of rarious kinds ornament the wayside. Then, too, the Composites often retain their winged and feathery fruit, to distribute by installments as the chance offers. Winter transmutes these dry forms into exquisite objects, bearding them with frost or clothing them with iridescent crystal.

Berries are always a conspicuous feature in a winter scene. The most showy of these is un- 
doubtedly the ilex or black alder. The leaves of this plant, unlike most hollies, are deciduous, and the twigs of the shrub are strewn with coral beads. They absolutely glow along the roadsides. Next to them in beauty hereabouts are the hawthorn berries and the hips of the wild rose. Sometimes a cluster of translucent barberries is found, even in midwinter. Of darkcolored fruit the most noticeable is the green brier, or wild smilax. In Rhode Island we also see everywhere the nearly black berries of buckthorn. The junipers have a blue fruit, very pretty when seen in the dark masses of evergreen foliage.

Speaking of evergreens calls to mind at once the frequency of green as a color even in the desolation of winter. All the coniferæ, except the larches, retain their leares and all are beautiful. Then, among the higher classes, we find such plants as the Rhododendron and the Kalmia or mountain laurel. The sides of trees are clothed with green mosses and liver-worts; the true mosses are often found, too, in fine shape on rocks or on the ground. Then, if we add the lichens, we greatly increase the range of color.

Many of the smaller plants continue verdant, the prince's-pine, the rattle-snake-plantain, the checkerberry, and many ferns. The green-brier or round-leaved smilax, is lovely at this season. Some of the leaves are glossy green, others red or yellow, and still others elegantly bronzed. 
Owing to their rigidity, these leaves keep well indoors, and there is no prettier ornament than a long vine of green-brier trailed about a picture. It has clusters of very showy, dark blue berries, in appearance not unlike the fruit of the little frost grape.

A more familiar ornament in winter decoration is the so-called black-alder, in reality a holly. The foliage is deciduous, and leaves the scarlet berries very prominent. These are much used in Christmas wreaths and crosses. The berries are, however, more beautiful when seen in the swamps, often glazed over with a cuirass of ice. The Roxbury wax-work is equally showy. It is sometimes known as climbing bitter-sweet, and must not be confounded with the nightshade of the same name. The yellow pods open and reveal a scarlet aril-covered seed. The climbing or twining habit of the plant makes it very graceful.

As long as there is no snow upon the ground, and there occurs an occasionally sunny day, we may find, late in December, some stray flowers of the earlier months. Dandelions not infre'quently bloom even as late as Christmas, but this little plant is very hardy-as it extends to the Poles. As for the tiny chickweed, beloved of canary birds, its blossoms are with us all winter. The severest weather only checks for a time the presumption of this valiant plant; it is a member of the Alpine Club of plants, and might climb the Matterhorn or Mount Blanc. 
Only let the sun shine upon it, and lo! outbeams its galaxy.

Among the weeds that linger latest are the yarrow, the evening-primrose, the bouncing-bet, the butter-and-eggs, and the self-heal. Certain butterfles remain as long. I have seen Vanessa: Antiopa, the Camberwell Beauty, floating. through the thickets, like an exile queen, a sort of Margaret of Anjou, mourning her former grandeur.

The tangles, or brambles, certain species of black-berry, preserve their autumnal colors all winter. These shrivel when brought in-doors, but in the woods are fresh at all seasons. It is the bramble of which old Elliott sings so. sweetly:

"Thy fruit full well the school-boy knows, Wild bramble of the brake!

So, put thou forth thy small white rose, I love it for his sake.

Though wood-briers flaunt and roses glow

O'er all the fragrant bowers,

Thou needst not be ashamed to show

Thy satin-threaded flowers."

Spicily fragrant is the bay-berry, which long retains its leares. Its gray clusters of fruit. survive the foliage, and are used in making. tallow.

The microscope reveals wonders of structure in the mosses, lichens, and fungi. Some of: these we have all winter. Certain fungi are seen projecting from the trees like a series of 
brackets, each one ornamented with concentric rings of black and white. There is no better time for collecting mosses than the present. Wrap the specimens in paper, with the name, locality, and date of collection. Whether known or not, collect; names may be determined later. In winter if one is a collector he has all his summer stores to examine. Often as he turns them over, he is led in imagination to the spot where he found them. Suppose it is a collection of plants he is viewing. Each specimen will recall pleasant scenes and delightful companionship. The storm outside has no longer a voice; he is in the woods with his pets, breathing sweet perfumes of leaves and flowers, listening to the merry birds, or chasing gaudy butterflies. The memory of the noon-day heat comes back to him; the little spring, half buried in moss, and fringed with ferns, the over-arching birches, and the "checquered shade."

It is the best time, too, to study buds and branches. The hazels, alders, birches, poplars, and sweet-ferns; the iron-wood, the hop-hornbeam, even now show their tassels. They are closely compacted, each scale closing orer the minute flowers, but many of them can be coaxed out in the house. It is always a delight to see them evolve,- the light, pendulous, graceful "tags" of alder are an especial joy. It is not an unusual thing to see the silver-leaf maple in full flower in February.

Crocuses and snow-drops sometimes shiver 
into bloom on sunny banks before the calendar ever mentions Spring. It is not, after all, astonishing. Do not the most delicate of plants embrace the feet of alpine snow-drifts? On the top of MIt. Washington, when the tourist is hugging his orercoat or shawl about him, the little mountain sand-wort is fluttering its white blossoms in the wind. By the Lake of the Clouds, fed by icy streams which one hears murmuring under the rocks beneath him, there grows, in summer, a perfect garden of flowers.

There is no time so good as this for learning the actual shape of trees. Look at the spire of the maple, the fountain-like spray of the elm, or the rounded silhouette of the horse-chestnut. Break off a branch, tack it against a wall and sketch it. You will discorer beauties of which you nerer dreamed. Open the buds. Observe that the naked trees are no mere skeletons. There are the little hands that will, ere long, beckon us back to the forest! 



\section{INDEX OF PLANTS.}

Adder's-tongue .......Erythronium Americanum....30

Yellow .........Erythronium Americanum....15

Alder .............Alnus sp......7, 8, 9, 120, 13 J

Black..........Ilex verticillata .......131, 132

Andromeda ...........Andromeda polifolic.......17, 18

Anemone ...........Anemone nemorosa. 3, 7, 8, 15, 24, 84

Rue ..........Anemonella thalictroides....15, 24

Star............ Trentalis Americana..........16

Syrian............................41

Wood...........Anemone nemorosa..........15

Anemonella . ........Anemonella thalictroides......15

Arbutus, trailing ........Epigcea repens. ...........19

Arethusa............ Arethusa bulbosa . .27, 40, 49, 50, 60

Arnica . ............Arnice Chamissonis........ 71

Arrow-arum...........Peltandra undulata.........61

Ash ...............Fraxinus sp ...10\%, 115, 116, 130

Mountain ......Pyrus Americana......30, 67, 84

Aspen..............Populus tremuloides ....100, 110

Aster..................

$76,83,95,97,105,109,119,120$

Acumerate-leaved. Aster acuminatus...........67

Golden topped.... Chrysopsis falcata.........6 64

.New England ....Aster Novœ-Anglice........88, 97

White topped... Sericocarpus conyzoides.... 64, 82

A vens, mountain ....... Geum radiatum var. Peckii.....71

Azalea............Rhododendron sp........17, 32

Alpine.......... Loiseleuria procumbens........ . 0

Dwarf .......... Loiseleuria procumbens.... . . . i2

Pink .......... Rhododendron nudiflom.... .32

White ........Rhododendron viscosum....59, 64 
Babies Breath ....... Galium sp ............61

Balsam, wild......... Impatiens fulten..........61

Baneberry ..........Actea alba............. $8 t$

Barberry.......... Berberis culguris...31, 82, 100, 131

Bayberry . ..........Vyrica cerifem . .110, 119, 120, 133

Bearberry..........Arctostaphylos alpina ....... \%0

Bedstraw .......... Galium sp........ . ....61

Beech ............. Fagus fermginare

25. $6 \hat{\imath}, 10 \%, 116,130$

Bellwort, perfoliate..... Cunlaria perfoliate..........15

Bilberry, bog......... Vaccinium uliginosum.... . . 0

Bindweed.......... Concolvulus sp......56, 57, 86

Birch ............ Betula sp.

10, 25, 67, 69, 100, 105, 106, 116

Dwarf ......... Betule glandulosa . .... . . 7

White ........ Betula populifolia ... ......13)

Birthwort.......... Trillium sp............29

Bishop's-cap ..... ... Vitella sp...... . .... . . 29

Bishop .reed, mock .. .Discopleura capillacer ...... 87

Bittercress, dwarf......Crardamine bellidifolir....... 69

Bittersweet .......... Solanum Dulcrmara........ 8:

Blackberry.........Rubus sp... . ..........133

Bladderwort, common. Etricularia vulgaris........62

Purple ........ Etricularia purpurea.......61

Yellow ....... Etricularia vulgaris........61

Bloodroot ........... Sanguinaria Canadensis... . . .15

Blucberry.......... Vaccinium sp........ .18, 100

Mountain....... Taccinium caspitosum.. . . . 70

Bluets .............. Houstonia cumlen.. ....... 16

Bouncing Bet ........Senonaria officinalis. .122, 130, 132

Bryanthus............ Bryanthens tr.xifolius...... . . 70

Buck-bean .......... Menyanthes trifoliatr..... . 26

Buckthorn ........Rhemnens catharticu........131

Bulrush, mountain. . ...scirpus crespitosus. ... . ...71 Bunchberry.......... Cormes Canadensis........30, 84 Bur-marigold..... .. . Bidens chrysanthemoides.. ... 98 Buttercup.........Ranunaulus sp...... 4, 38, 42 
Butterwort .........Pinguicula vulgaris.........70 Butter and Eggs ......Linaria vulgaris........55, 133 Butterfly-weed ........Asclepias tuberosa..........63 Button bush ......... Cephalanthus occidentalis. ... 64 Calico bush.......... Kalmia latifolia......... . 40 Calla ............. Calla palustris............ Calopogon ..........Calopogon pulchellus......50, 60 Caltha ......... . Caltha palustris...........98 Calypso............Calypso borealis........27, 28 Camphor weed .........Plucher camphorata..........86 Campion, moss ....... Silene acculis............69 Cardinal-flower .........Lobelia cerdinalis..75, 76, 77, 83, 95 Carrot, wild..........Daucus carota.........122, 130 Cassia ............Cassic chamacrista.........79 Cassiope............Cassiope hypnoides........70, 72 Checkerberry .........Gautheria procumbens.......131 Chestnut .......... Castanea sativa var. Americana,

Chickweed ...........Stellaria media.....5, 68, 122, 132 Chicory... .........Cichorium Intybus.. .....64, 95 Chokeberry ... .......Pyrus arbutifolia...........30 Cinquefoil...........Potentilla Canadensis......15, 87 Alpine ......... Potentilla frigida... . .....69 Clematis ............ Clematis Virginiana,

Clethra ........... Clethre alnifolia....... .76, 83

Clintonia...........Clintonia borealis........30, 84 Cloudberry ........Rubus Chamaemorus.....67, 71 Clover............ Trifolium sp...............

Hybrid ........ Trifolium hybridum .... . . . .443 Columbine...........Aquilegia Canadensis........16 Cone flower ......... Rudbeckia hirt ........40, 55 Coreopsis ........... Coreopsis rosen........... 98 Coruel ............Cornus sp............100, 108

Dwarf ..........Cornus Canadensis...........30 Cowberry............ Vaccinium Vitis-Idcea .......71 Cowslip (so-called) .....Caltha palustris...........17 $12^{*}$ 
Cow-wheat. .. .........Velempym Americanum.....59 Cranberry, mountain.... Veccinium Vitis-Idaer.. . . . .7.71 Creeping Jenny ....... Lycopodium complanatum ....121 Crocus ............. Crocus verna........... 135 Cudweed, mountain.... Gnaphalium supinum... ...ro Cycads.... .........Sago-palms.............. Cypripedium ......... Cypripedium acaule . .......27 Daffodil.............. Narcissus sp............42 Daisy.............Chrysanthemum leucanthemum,

$4,40,42,55,60,96$ Mountain.......Arenaria Groenlandica......6.68

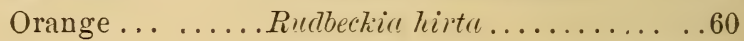
Ox-eye ........Chysenthemum leucenthemum,

37, 109

Dandelion............Taraxacum densleonis,

$4,13,38,96,122,132$

Autumn..........Leontodon autumnale....... . 109

Dewberry...........Pubus Canadensis... .......111

Devil's apron.........Laminaria......... ....111

Diapensia...........Diapensia Lapponica....68, ז0, 72

Dicksonia........ . Dicksonia pileoscula..... .. 106

Dodder.... ......... Cuscutu Gronocii... . . ....80

Dogbane, spreading .... Apocynum androscemifolium . . .63

Dogwood, flowering.... Comme florida. . ......... 30

Dulse .............................. . .

Elder ..............Sambucus Canadensis . . ....83

Elm .............. Climus Americana,

$3,84,115,129,135$

Everlasting ......... Gnaphalium polycephalum..... Eyebright.......... Euphrasia officinalis......... 71 Ferns.................... .. 100, 106, 118 Fever-bush........... Lindera benzoin............18

Fire-weed ........... Epilobium angustifolium..... 60 Fire-weed... . . . . . Erechthites hieracifolia... . ... 78 Five finger......... Potentilla Canadensis.... ...15 Flag lily ........... Iris rersicolor............41 Floating-heart.......... Limnanthemum lacunosum. ...48 
Forget-me-not ........Myo:otis lux (...........99, 109

Foxglove, false ....... Gerardic sp........... 56,80

Gaulheria............ Gaultheria procumbens........64

Gentian, box..........Gentiane Andrersii....... ir, 98

Closed .......... Gentiena Andreersii....... . 7 , 9.5

Fringed ........Gentiena crinite..i7, 99, 105, 109

Geranium, wild ........ Gerenium maculetum .... . . 30

Gerardia.. ..........Gerrertie sp........ 80, 87, 95

Dainty purple....Gerardin tenuifolia ....... ...81

Purple .........Gererdia purpurea ..........86

Salt marsh........Gererdia maritima ...........81

Geum, Pecks...... ... Geum radiutum var. Peckii...68

Ginger, wild..........Asemem Canadense ........24

Golden-rod .......... Solidtugo sp

$64,68, i 5,76,82,83,95,105,109$

Alpine .......... Solidugo Tirgeurea ........... it

Axile-leaved .... Solidago cessic.............105

Lance-leaved.... . Solidago lenceolate........... 8s

Maritime ........ Solidago sempertirens. ........si

Mountain... .... Solidago Virgeutree.........67

Rigid-leaved... ...solidago rigidd.............97

Seaside ......... Solidago sempertirens........ s8

Wars-leared...... Solidago undulute..........105

Grape ............. Vitis sp.................101

Grass-bur ........... Cenchins tribuloides..........si

Hair.... . ..... Deschampsia coespitose ....... is

Hedge-hog...... Cench rus tribuloides.......... si

Holy... . . . .....Hierochtod alpina.............i1

of Parnassus......Pernassia Ceroliniena...... 101

Reed ........... Phragmites sp .............s

Whitlow........ Drebre vernu................

Greenbrier............ Smitax rotundifolie .111, 131, 132

Ground nut.........Apios tuberosin......... is, $8: 3$

Groundsel ............Senecio vulgaris...........122

Hardhack............ Spireer tomentosa .........82, 83

Harebell..... . . ...... Cumpanula rotundifolia.......61

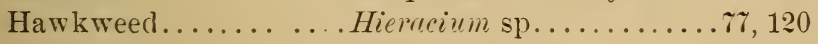


Hawkweed, Orange.....Hieraacium auranticum .....43 Hawthorn.......... Cratcegus sp............131 Hazel ............Corylus, .....7, 8, 9, 10, 120, 135 Beaked ........ Corylus rostrata ............10 Heal-all ....... . ....Brunella vulgaris..... . . . . 39 Hellebore ....... ......... . ........5, 13 False or white... Veratrum viride...........67 Hemlock...........Tsuga Canadensis...........117 Hemp, Indian......... Apocynum cannabinum.......63 Hepatica ............ Hepatica triloba..... 8, 12, 14, 15 Hickory.............. 25, 100, 107, 111, 116, 129 Holly.............. Ilex opaca........117, 120, 131 Honeysuckle, bush ... . Diervilla trifida............32 False..........Rhododendron nudiflom..... 32 Fly............ Lonicera ciliata . . . ........32 Mountain fly... . Lonicera caerulea........... 32

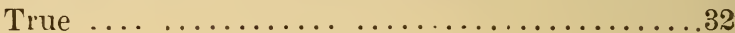
Hornbeam, hop......... Ostrya Virginica..........135 Horse-chestnut........ Esculus Hippoccistanum,

$3,116,135$

Huckleberry..........Gaylussacia sp......18, 111, 112 Indigo, wild ..... . . ..Baptisia tinctoria . . . ..79, 119 Ilex ............... Ilex sp ............. 131 Indian paint brush...... Crestilleic coccinea..........27 Indian pipe............Yonotropa, uniflor ........65

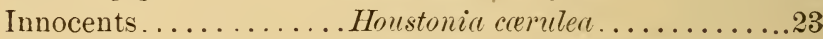
Iron weed ........... Vernonia noveboracensis . . . . 77 Ironwood .......... Ostrya Virginica...115, 130, 134 Iris .............. Iris sp.............. . . Ivy, poison .. .......Rhus toxicodrendron..... 84, 100 Jack-in-the-pulpit ...... Ariscrema triphyllum.17, 25, 84, 101 Jewel-weed .. .... . . Impatiens fulva.......... 61 Juniper............Juniperus communis. .68, 117, 131 Kalmia ........... Kalmia sp...........45, 131 Ḱnotweed, alpine .....Polygonum vivipamum... ...7.71 Heath-like ...... Polygonella articulata ...... . 88 Lady's slipper......... Cypripedium acaule.........49 
Lady's slipper, showy. . Cypripedinim spectrbite.......2i

Yellow ........ ('ypripedium pubescens. ......24

Larch ......... . . . . Lerix Anevicana........... 131

Lambkill, common .. .. Krelmin! ungustifolie......... 46

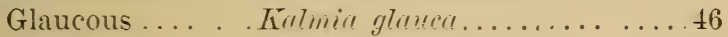

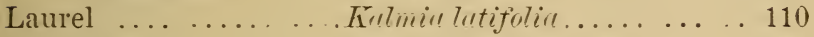

Great.......... Rhendodendron maximum..... 64

Mountain... ... Kalmial latifolid,

$1 \%, 18,45,11 \%, 131$

Lavender, seaside ...... Stutice Limonium var. Caroliniuna,

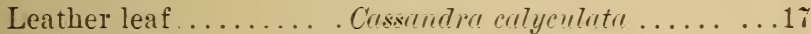

Lettuce, wild .........Luctuce Conadensis.........120

Life everlasting....... Gruephatium prolyceptertum....10z

Lilac...............syringa melgaris. .......3, 116

Lily....... . . . . ..Liti!ni sp.............5.5, 68

Canadian.........Lilium C'unuderise........ 40

Field .... ... . .................... 59

Philadelphian .. Lilium Philudelphicum ......40

Trinity ....... Trillinm sp. ............29

Turk's cap ...... Litium s"perbum.... . . . . .40

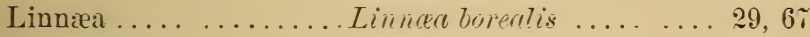

Liverwort . . . . . . . . . . Hepatica tritoba... . . . . . . . . . 14

Locust ............ Robinia psendacencia... ..... i9

Honey ........ Gleditschia .............121

Loosestrife, purple .. .. Lythrum Salicariu .... . ...660

Shrubby . ... Decorlon rerticillatus. ........59

Yellow ........ Lysimactiou sp.. .........660

Lotus ... .......................... . . . .

Lupine ... ........ Lupinus perennis... .......33

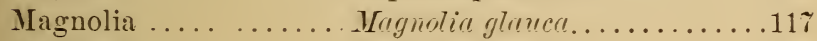

Maiden's-tresses . . . Spiranthes sp .............99

Mallow, rose .......... Hibiscus Moschentos . . . . . . . . 59

Maple................ Acer sp.

3, 千, 84, 10 $, 110,112,126,135$

Red...........Acer mbrum ..........15, 100

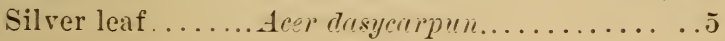




\section{NEW ENGLAND WILD FLOWERS.}

Maple sugar..........Acer saccharinum ..........117 Marigold, marsh... . ..Calthe palustris.........13, 17 Mayflower ......... Epigcea repens . ........8, 13 Mayweed ..........Arthemis Cotula.......109, 122 Meadow beauty.......Rhexia Virginica.......60,83

Meadow sweet.........Spirae salicifolia......... 82

Menyanthes..... . ..Menyanthes trifolia........ 26

Mikania ....... . ...Mikania scandens............78

Milkweed, common ...Asclepias Cornuti..........63

Four-leaved .....Asclepias quadrifolia .......6.63

Poke ..........Asclepias incarnata........63

Mitella .............. Vitella diphylla ............29

Mitrewort............ Vitella diphylla . ........ 29

False ........Tiarella cordifolia.......... 29

Moneses................ Voneses grandiflor ..... . . . .48

Money.............. Lysimachia nummularia..... .88

Monkey flower ........Mimulus ringens...........77

Morning glory, wild....Ipomoea purpurea.. ....... 5 7

Mullein.......... . . Verbascum Thapsus.........56

Moth .......... Verbascum Blattaria........556

Nightshade, enchanters. Circœa Lutetiana...........61

Nymphæa ........... Nymphcea odorata... ....46,47

Oak .............Quercus sp..100, 107, 112, 120, 129

Orchis, mountain.......Habenaria obtusata.... .... 71

Purple-fringed. . Habenaria psycodes...........50

Show y......... Orchis spectabilis . . ......24

Painted cup...........Castilleia coccinert.......26. 27

Alpine.......... Castilleia pallida...........70

Palms ................. ............ ...

Parsnip, water . ...... Sium cicutcefolium....... 87

Partridge-berry ......Vitchella repens............48

Pea ..............................79

Beach ........ Lathyrus maritimus ... .76, 86, 88

Pennycress .....Thlespi arcense.............87

Pickerel-weed .........Pontederia cordata......... 87

Pigweed...........Amarantus retroflexus........87

Pimpernel.... .......Anagallis Arvensis .........86 
Pimpernel, water...... Simolus Talerandi var. Americanu.s

Pine.............Pinus sp..............117

Ground......... Lycopodivm complanatum....121

Pink, wild... ....... Sitene Pennsyleanica ........130

Pitcher plant..........surracenia purpurea........62

Plaintain, long-leaved. . Plentrgo lanceolata.......... 38

Rattlesnake..... Goodyera repens............131

Pogonia.............Pugonia ophioglossoides. .40, 49, 60

Poke-weed...........Phytollacer decandra..8t, 100, 110

Polygala, fringed.......Polygala panciflora... . . . .27

Pond-lily ............ Tymphoea odorata ...46, 55, 79, 83

Pink .......... Tympheed odorata .... ....48

Yellow ... ...... Vuphar advena. . .........47

Poor man's weather glass. Anagallis Amensis .......... 86

Poplar............Populus sp.......10, 129, 134

Potentella ...........Potentilla sp............. 15

Canadian ........Potentilla Canadensis....... 15

Silver-leaf....... Potentilla argentea.... . . ...15

Primrose, biennial..... Enothera biennis...........

Dwarf........ Enothera sp........... . 9 , 87

Evening .......Enothera biennis.79, 109, 130, 132

Prince's pine. ........Chimaphila umbellata....117, 131

Pyrola.............. Pyrola sp ................64

One-flowered ..... Yoneses grandiflora........ 48

Quaker ladies.........Honstonia cernlea...........

Ragwort, golden ...... Senecio aureus.. .......26, 27

Rattlesnake root.......Prenanthes sp.......... 5s, 70

Rhododendron..........Phododendron maximum...64, 131

Mountain....... Rhododendron Lapponicum ... . . 2

Rhodora ............Rhododendron Rhodora.... . . 18

Ribgrass ......... Plantago lanceolate.........38

Rose.............Rosa sp.........43, 4t, 5.5, 131

Rose-bas ..........Rhododendron maximum...64, 117

Alpine..... . . . Phododendron Lapponicum.... . r0

Rosemary, marsh....... Statice Limonium var. Corotiniona, 
Rowan, American......Pyms Americana... . ......667 Rudbeckia ......... Rudbeckia hirta .......40,5.j Rue, meadow. ........Thatictrum polygamum... ...60 Rush, sedge.......... Carex capitata, C. atrote var. Ocata C. volgaris var. hypoborere. . 11 Wood............Luzula arenatr, L. spicata.....71 Sabbatia........... Sabbutia Chloroides..........85 Saltwort............ Srelsola kiali............. si Sandwort, alpine.......Arenaria Groenlandica .......68 Mountain .........Arenario Groentandica .... . . is

Sea.............trenaria peploides......... 87 Samphire ...........sesticornia mucronate ....... . si Sassafras............ Sassiffres officinale.......18, 100 Saxifrage........... Saxifraga sp...........

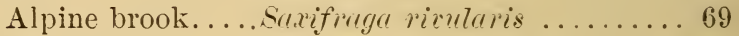

Mountain ....... Saxifreaga oppositifolia.......69

Tellow mountain. Saxifiaga aizoides...........70 Sea-sand weed .........Arenaria peploides.......... 8i Sedge ........... . Carex sp ......... .... . . 1 Sedge-rush........ . Cerex sp................ Self-heal............Brunella vulgaris ....39, 109, 133 Shadbush. . .........Ametenchier Canadensis ..... 15 Shin-leaf........... Pyrold elliptica ..... . . ... 64 Sibbaldia........... Sibbaldia procumbens.......69 69 Silk-weed........... Asclepirs Cornuti...........63 Silver-weed............Potentilla Anserina.......... .86

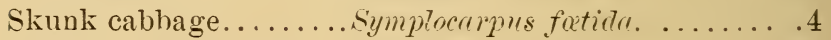
Smilax, round-leaved. . Smilax rotundifolir............131 Wild ............smitax rotundifolia..........131 Snap-dragon, wild...... Limaria vulgaris ..........55 Snowberry, creeping.... Chiogenes hispidula ......... 18 Snowdrop.......... . Galanthus. . . . . . . . . . . . 135 Solomon's Seal, false.... Yairnthemum Cunadense .. 31, 84 True ......... Polygonatum biflom ........ 31 Sorrel...............Rumex acetosella............

Mountain.... . Oxyria digyna ... . . . . . . . . 90 Sheep ....... Rumex acetosella...........39 
Sorrel, wood...........entis acetosella..........67

Spartina ........... Spartina sp. ............ss

Speedwell .......... Teronica officinalis.......39, 50

Alpine......... Téronica alpina............70

Spice-bush ..........Lindera Benzoin..........15

Spoonwood .......... Falmia latifolia...........46

Spruce...........Piced sp..........67, 69, 117

Spurrey ........... Spergnta arensis..........8r

Star of Bethlehem ..... Ornithogalum... . . ......16

Starwort, water...... Callitriche verna............

Strawberry .........Fragaria sp ...........16

Sumac............Rhus sp ...84, 100, 11, $, 107,111$

Sundew, common ......Drosera rotundifolia........62

Red-flowered.....Droser filiformis.........6. 62

Sunflower............Helianthus sp............96

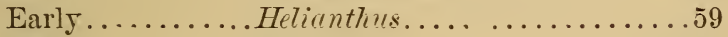

Wild..........Helianthus............64, 88

Swamp cheese........ . Rhododendron viscosum.... . . 32

Sweet fern ...........Yyrica asplenifolia.......10, 134

Sweet pepper-bush ..... Clethra alnifolia........... . 6

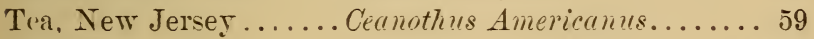

Thistle ............ Cinicus .............

Thornapple.......... Datura Stamonium. ... ....130

Thoroughwort.... . . . Eupatorium perfoliatum...76, 83

Climbing ........ Mikania scandens............

Purple....... Eupatorium purpureum......7\%

White.........Eupatorium perfoliatum...... is

Tiarella............. Tiarella cordifolia ......... 29

Tick-trefoil .........Desmodium sp............ is

Toad-flax......... . Linaria vulgaris... ........5

Blue............tinaria Canadensis. .......86

Tobacco, Indian....... Lobelia inflate............. 6

Touch-me-not, wild .... Impatiens fulva. ........6. 61

Trillium........... . Tritlium sp.............28

Painted........ Tritlium erythrocarpum .......29

Purple......... Tritlium erectum ...........29

Trisetum............Trisetum sp.............. 
Tulip tree............Liriodendron Tulipifera .....117

Tupelo.............. Nyssa sylvatica........83, 129

Turtle head........... Chelone glabra..........77. 95

Venus's fly-trap....... Dionce muscipula.........62

Venus's looking-glass... Specularia perfoliata... . . . 886

Veronica ........... Teronica sp. ... ..........39

Violet............ Tiola sp....... 3, 8, 23, 126, 127

Bird-foot ....... Tiola pedata.............23

Downy jellow.... Tiola pubescens......... . . ..24

Marsh.......... Viola palustris........... 69

White ......... Tiola blanda.............23

Yellow ........ Tiola rotundifolia ..........24

Virgin's Bower.........Clematis Tirginiana .......81

Watershield...........Brasenia paltata..........48

Waxwork, Roxbury... Celastrus scandens. ... . .82, 132

Whiteweed .........Chrysanthemum leucanthemum.37

Willow...........Salix ............ 9,69

Bearberry ........Salix uva-ursi .............

Dwarf..........Salix phylicifolia.......... r0

Herbaceous ...... Salix herbacea ..............70

Willow-herb, alpine.... Epilobium Hornemanni...... 70

Witch hazel..... ......Hamamelis Tirginiana.......110

Woodbine ...........Ampelopsis Tirginica ....82, 100

Wormwood, salt water...................... 86

Yarrow .............Achillcea millefolium,

$109,120,122,133$ 


\section{INDEX OF SCIENTIFIC NAMES.}

Arctostaphylos alpine $\ldots \ldots \ldots \ldots \ldots \ldots$. . . . .

Arenaria Groenlandica. ....................71

Arnica Chamissionis $\ldots \ldots \ldots \ldots \ldots \ldots \ldots \ldots . \ldots . \ldots 9$

Aster lævis.............................. .

Betula glandulosa.......................

Bryanthus taxifolius...................... 70

Cardamine bellidifolia... . . . . . . . . . . . . 69

Atrata var. ovata $\ldots \ldots \ldots \ldots . \ldots . \ldots 71$

Carex capillaris............................

Capitata.......................... .

Vulgaris var. hyperborea.................71

Cassiope hypnoides.....................70

Castilleia pallida var. septentrionalis . ........... 70

Deschampsia caspitosa.....................71

Diapensia Lapponica...................... 70

Empetrum nigrum $\ldots \ldots \ldots \ldots \ldots \ldots \ldots \ldots \ldots \ldots$

Epilobium Hornemanni................... . 0

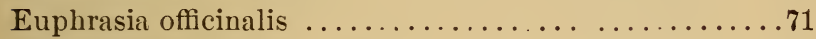

Geum radiatum var. Peckii ................. 71

Gnaphalium supinum .................... 70

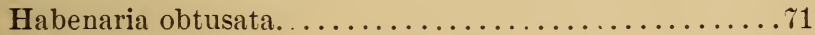

Hierochloa alpina .................... . . . .

Iris Florentina........................... 42

Luzula arcuata..........................71

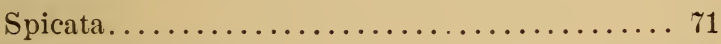

Loiseleuria procumbens ................ 70

Oxysia digyna ......................... 70

Pinguicula vulgaris.... ................ 70

Polygonum viviparum ...................... 71

Potentilla frigida....................... 69 
Prenanthes Boottii.......................

Serpentaria var, nana. ................ . 70

Rhododendron Lapponicum..... ............70

Rubus Chamæmorus ...................... 1

Salix argyrocarpa......................

Herbacea........................... . . .

Phylicifolia....................... .

Uva-ursi............................. 70

Saxifraga aizoides.......................

Aizöon ...........................70

Oppositifolia .......................69 69

Rivularis....................... . . .

Stellaris var. comosa.. ................ r0

Scirpus cæespitosus .... . . ...............71

Silene acaulis........................... 69

Sibbaldia procumbens... $\ldots \ldots \ldots \ldots 6$

Solidago arguta..... . . . . . . . . . . . . . 96

Cæsia.............................. . .

Nemoralis.......................... 96

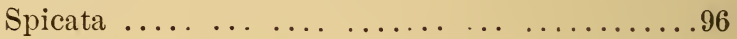

Virgaurea var. alpine................71

Trisetum sub-spicatum ................. . . .

Vaccinium crespitosum.................. .

Uliginosum . .....................

Vitis-Idæa ... .................... . . .

Veronica alpina....................... 70

Viola palustris........................69 


\title{
PUBLICATIONS
}

\author{
OF \\ PRESTON AND ROUNDS,
}

PROVIDENCE, R. I. 



\section{History of the State of Rhode Island and Providence Plantations, 1636-1790.}

\section{BY SAMUEL GREENE ARNOLD.}

New Edition. 2 vols. Octavo. 574 and 600 pp. $\$ 7.50$, net.

Governor Arnold's History of Rhode Island, based upon a careful study of documents in the British State Paper Office and in the Rhode Island State Archives, supplemented by investigations at Paris and The Hague, has from its publication been the authoritative history of the State.

Genealogical students will find in these volumes the names of over fifteen hundred persons prominent in Rhode Island affairs. This work is of much more than local interest, as the experiment of religious liberty here tried gives to this history an importance far beyond the narrow limits of the State.

"One of the best State histories ever written is S. G. Arnold's History of the State of Rhode Island and Providence Plantations." - JoHN Fiske.

"The best history of Rhode Island is that of Arnold." - Prof. George P. Fisher, Yale University.

"Mr. Samuel Greene Arnold in his history of Rhode Island has brought together all the extant materials. He brings out more clearly than any previous writer the distinct threads of the previous settlements." - Prof. JohN A. DOYLE, Oxford.

"A work prepared after long and careful research. Probably no student has ever made himself more familiar with the history of Rhode Island than did Arnold. This work abounds, therefore, in valuable information." - Pres. Charles Kendall Adays, Cornell University.

SENT POSTPAID BY THE PUBLISHERS. 


\title{
Among Rhode Island Wild Flowers.
}

\author{
By W. WHITMAN BAILEY, \\ Professor of Botany, Brown University.
}

Cloth. I6mo. Three full-page Illustrations. 75 cents, net

This admirable little volume, the outgrowth of the author's ripe experience in teaching and in botanizing, contains a popular and interesting account of Rhode Island wild flowers as distributed throughout the State. The favorite collecting grounds are fully described, thus forming a botanical guide to Rhode Island.

In writing this volume Professor Bailey has had in mind the needs of the nature lover, and has discarded technical terms as far as possible, adapting the work to the amateur as well as the botanist.

It should be in the hands of every lover of woodland and meadow.

Forwarded postpaid to any address upon receipt of price by the publishers. 


\title{
Tax Lists of the Town of Providence
}

\author{
During the Administration of Sir Edmund Andros \\ and his Council,
}

\section{$1686-1689$.}

\author{
Compiled by EDWARD FIELD, A.B., \\ Member of the Rhode Island Historical Society, and one of the \\ Record Commissioners of the City of Providence.
}

Cloth. Octavo. $60 \mathrm{pp} . \$ \mathrm{I} .00$, net.

The "Tax Lists of the Town of Providence" is a compilation of original documents relating to taxation during the Administration of Sir Edmund Andros and his Council, I686-I689. It comprises copies of warrants issued by order of the Council for the assessment and collection of taxes, the tax lists or rate bills prepared pursuant to these warrants, the returns made by the townsmen of their ratable property, and the Tax Laws enacted by Andros and his Council. All of these, with the exception of the laws, are here printed for the first time.

Among the rate bills is the list of polls for 1688, which contains the names of all males sixteen years of age and upwards living in Providence in August of that year; practically a census of the town. For the genealogist and historian this volume contains material of the greatest value on account of the great number of names which these lists contain, besides showing the amount of the tax assessment in each case.

The returus of ratable property form a study by themselves, for they tell in the quaint language of the colonists what they possess, and therefore shed much light on the condition of the times. For a study of this episode in New England Colonial History this work is invaluable.

The index of all names contained in the lists and text is a feature of this work.

The edition is limited to two hundred and fifty numbered copies.

Sent postpaid to any address on receipt of one dollar. 


\section{Early Rhode Island Houses.}

An Historical and Architectural Study by Norman M. Isham, Instruc tor in Architecture, Brown University, and ALBERT F. BROwN, Architect. Illustrated with a map and over fifty full-page plates. $\$ 3.50$, net.

No feature in the study of the early life of New England is more valuable or more interesting than the architecture. Nothing throws more light on the home life of the colonists than the knowledge of how they planned and built their dwellings.

Early Rhode Island Houses gives a clear and accurate account of the early buildings and methods of construction, showing the historical development of architecture among the Rhode Island colonists, the striking individuality in the work of the colony and the wide difference between the buildings here and the contemporary dwelling in Massachusetts and Connecticut.

Those interested in colonial life may here look into the early homes of Rhode Island with their cavernous fireplaces and enormous beams. The student will find in these old examples a valuable commentary on New England history, while the architect will discover in the measurements and analyses of construction much of professional interest.

Among the houses described are the Smith Garrison House and the homesteads of the families of Fenner, Olney, Field, Crawford, Waterman, Mowry, Arnold, Whipple, and Manton.

A chapter is devoted to the early houses of Newport, which were unlike those of the northern part of the State and resemble the old work in the Hartford colony.

Photographs and measurements of the dwellings have been made, and from them careful plans, sections, and restorations have been drawn; in some cases six full-page plates admirably drawn and interesting in themselves have been devoted to a single house. Several large plates give illustrations of framing and other details. It is to be noted that these plates are made from measured drawings, that the measurements are given on the plates, and that these constitute in most if not all cases the only exact records for a class of buildings which is destined to disappear at no distant day. It is believed that these drawings, and especially the restcrations, will give a clearer idea than has ever before been obtained of the early New England house. A map enables the reader to locate without difficulty the houses mentioned in the text.

The authors have discussed the historical relation of Rhode Island work to contemporary building in the other New England colonies and in the mother country. The book is a mine of authentic information on this subject.

A list of the houses in the State built before 1725 , so far as they are known, with dates and a brief description will be found in the appendix.

"This book is probably the most valuable historic architectural treatise that has as yet appeared in America." - The Nation. 


\title{
THE EAST INDIA TRADE
}

\section{OF PROVIDENCE,}

\author{
From 1787 to 1807.
}

BY GERTRUDE SELWYN KIMBALL.

By a careful study of log books and commercial papers of the old shipping firms, the author is enabled to present an interesting picture of the East India Trade of Providence in its palmy days.

8vo. 34 pages, paper, 50 cents net.

Sent postpaid on receipt of price. 


\section{THE MAGAZINE}

....OF....

\section{NEW ENGLAND HISTORY. FOR 1891, 1892, 1893.}

Having purchased the few remaining camplete sets of the Magazine of New England History, originally published at $\$ 6.00$, we offer the three volumes in parts as issued for $\$ 2.50$ net per set or bound in one volume, cloth, for $\$ 3.50$ net.

These volumes contain nearly eight hundred pages of information relating to New England local, church and family history, including. records, genealogies, journals, letters and many interesting notes and queries.

\section{WHAT CHEER$$
-\mathrm{OR}-
$$

\section{ROGER WILLIAMS IN BANISHMENT.}

A Poen by Job DURfee.

Rerised and edited by Thomas Durfee.

Cloth, Leather Label, 12 mo., 225 pages. Price $\$ 1.25$ Net 


\section{TOPOGRAPHICAL ATLAS}

OF THE

\section{STATE OF RHODE ISLAND AND PROVIDENCE}

\section{PLANTATIONS.}

\section{By the United States Geological Survey, in co-operation with the State.}

Having secured the remaining copies of this Atlas we offer them at the following reduced prices.

$\begin{array}{lr}\text { In sheets, } & \$ 1.00 \\ \text { In portfolio, } & 2.00 \\ \text { Bound in cloth, } & 2.50\end{array}$

A few bound in half morocco remain and can be furnished for $\$ 3.50$.

The plates of this Atlas were engraved upon copper in the highest style of cartographic engraving by the United States Government and furnished to the State. From these plates trausfers were made to stone anc the maps printed in four colors, viz: The names, roads, railroads and otber culture features are in black. Rivers, ponds, stramps and other water features are in blue. Contour lines and figures denoting eleration are in brown. State, county and to $\pi n$ boundaries are in pink over the more exact boundaries in black or blue.

Besides showing all bocies of water and water courses, common roads or highways and railroads, it has one feature distinct from and superior to any map of the State hitherto published, viz: Contour lines, drawn for each 20 feet of elevation above mean sea lerel, Figures are placed upon the heavier contour lines which denote elerations of 100 feet, 200 feet, etc., above mean sea level, also upon hills and bodies of water to denote their elevation. A contour line indicating 20 feet depth of water below mean sea level is drawn along the coast. In a few cases figures are given to indicate depths of water of less than 20 feet.

This Atlas includes 12 maps and 10 pages index and statistics in all 22 sheets $21 \times 16 \frac{1}{2}$. The scale of the survey is $\frac{1}{62} \frac{1}{500}$ or one mile to an inch. 


\section{MARY DYER}

OF RHODE ISLAND,

The Quaker Martyr that was Hanged on Boston Comnon, June 1, 1660.

BY HORATIO ROGERS,

Associate Justice of the Supreme Court of Rhode Island.

The author has gathered from many sources the scattered facts relating to the career of Mary Dyer and woven them into a detailed narrative, so that the tragic story of her life is now for the first time adequately told. By adding a brief but comprehensive sketch of the manner and sentiments of her times he has furnished a background or framework for his subject which adds much to the interest of the volume by enabling the reader the better to understand the surroundings of the characters he portrays. The important documents relating to her trial are printed in the appendix.

Cloth, 12mo., 115 pages. Price $\$ 1.00$ net.

Sent postpaid upon receipt of price by the publishers. 


\section{A Summer Visit of 'Three Rhode Islanders to the Massachusetts Bay in 1651.}

Bx HExRY MELTILLE KING,

Pastor of the First Baptist Church, Provídence, R. I.

Cloth, 12mo., 115 pages. Price $\$ 1.00$ net.

Uniform with "MARY Drer."

Ax account of the visit of Dr. John Clarke, Obadiah Holmes and Johx Crandall, members of the Baptist Church in Newport, R. I., to Winliajr Witter of Swanipscott, Mass, in Juti, 1651: ITS INNOCENT PURPOSE AND ITS PAINFUL CONSEQUENCES.

"Dr. King's pungent and conclusive essay is a timely contribution. He adduces competent evidence refuting the gratuitous insinuations of Palfrey and Dexter, who charged the Rhode Islanders in question with sinister political motives and excused their alleged maltreatment on that ground. Citations from original documents, with a bibliography, put the reader in position to verify the allegations of the author."-The Watchman.

Sent postpaid upon receipt of the price by the publishers. 


\title{
Revolutionary Defences in Rhode Island.
}

\author{
An Historical account of the Fortifications ani) \\ Beacons erected duing the American Revolu- \\ tion, Witi Muster Rolls of the CoMpanies sta- \\ tioned aloxg the Shores of Narragarsett Bay. \\ witil Maps, Plaxs axd Illustrations.
}

\section{B I EDWARD FIELD.}

Past President of the Rhode Island Society of the Sons of the American Revolution.

Cloth octayo, with 29 Illustrations axd Two Maps. Price \$2.25 NET.

This rolume contains an account of the rarious works of defence erected in the State of Rhode Island during the Rero lutionary War, showing where and under what circumstances they were built, and the names of the officers and enlisted men located at many of them at various periods of the war.

For nearly three years the British Army was located within the State and one of the notable battles was fought within its territory. The war map of this battle of Rhode Island, now preserred in the State archives, has been especially reproduced for this work, and is shown in its entirety for the first time.

The work is profusely illustrated with plans and riens of these old earthworks, together with illustrations of the styles of equipments and fac-similes of enlistment papers for the Continental Army. A Map of the State of Rhode Island is inserted showing the location of each fort, beacon, and coast guard station described in the text.

Muster rolls and company lists containing the names of more than seren hundred officers and enlisted men, many of which hare been hitherto inaccessible, are here presented. The records of Rhode Island Soldiers in the War of the Revolution are scattered and incomplete, and the names contained in this book will be of great assistance to those who desire to ascertain the service of Rhode Island Soldiers, or to establish their right to membership in the hereditary patriotic societies, for the names hare been carefully transcribed and reference is given in each case where the original muster or pay roll may be found.

Sent postpaid upon receipt of price by the publishers. 


\title{
NEW ENGLAND WILD FLOWERS AND THEIR SEASONS.
}

\author{
BY \\ PROFESEOR OF BOTANY IN BROWN UNIVERNITY
}

Cloth, 16mo. Uniform with "R. I. Wild Flowers." 75 cents net.

From long wanderings afield the author has caught the charm of the varying moods of our New England year and pictures them for the reader with sympathetic touch.

The characteristics of the conspicuous and dominant flowers of the months are sketched in broad lines, rendering identification easy.

The flowers of the White and Green Mountains - our alpine flora - receive separate treatment, as do also the flowers of the sea-shore-our coast flora.

Sent postpaid upon receipt of price by the publishers. 


\section{SAMUELL GORTON :}

FIRST SETTILE OF WARWICK, R. I.

A FORGOT'TÉN FOUNDER OF OUR LIBERTIES

Br LEWIS G. JANES, M. A.

PRESIDENT OF THE BROOKLYN ETHICAL ASSOCIATION

Cloth, 12mo. Price $\$ 1.00$ net. Uniform with "Mary Dyer" and "Summer Visit."

A careful, conscientious and sympathetic study of one of the most unique figures in our colonial history, and of some of its most exciting episodes.

It is the first systematic attempt to give candid and judicial interpretation of Gorton's peculiar religious views, and is of equal interest to the theologian and historical student.

Sent postpaid upon receipt of price by the publishers. 



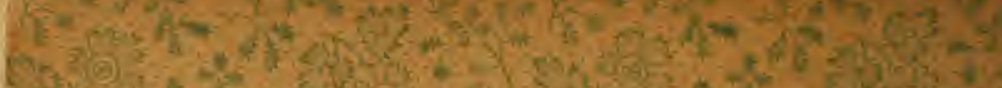

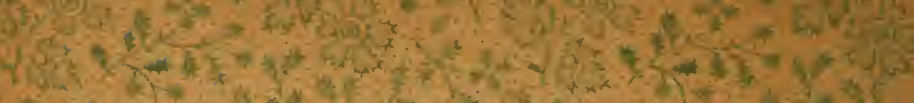

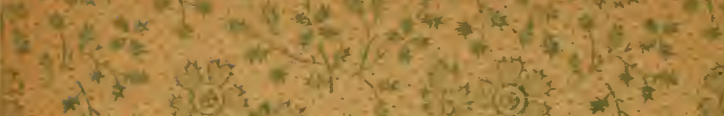

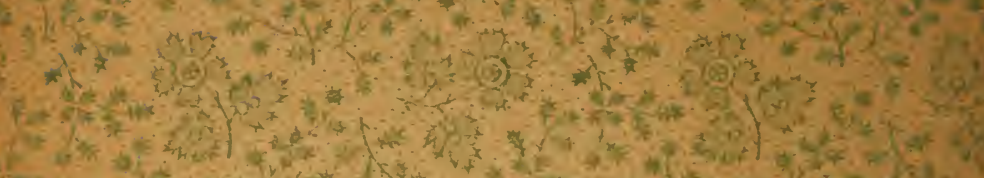

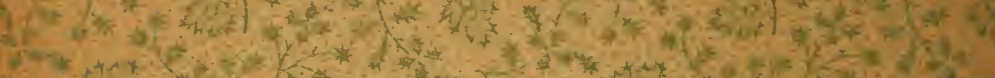

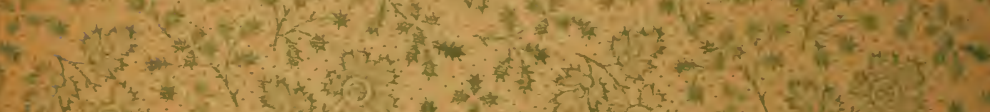

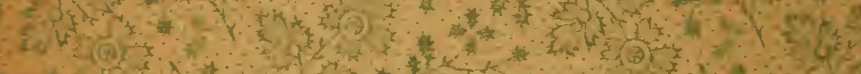

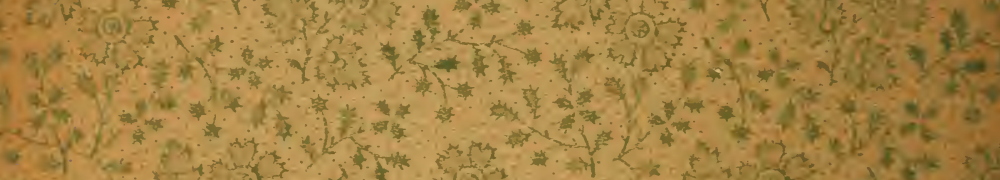

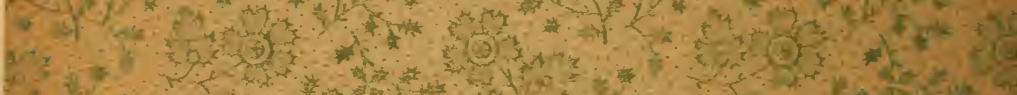

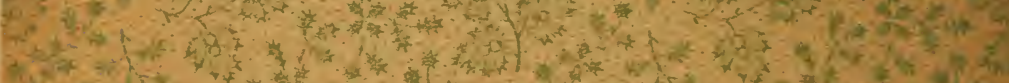

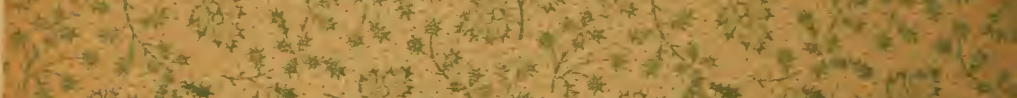

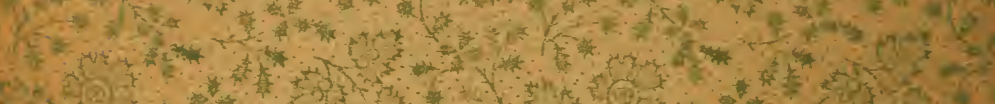

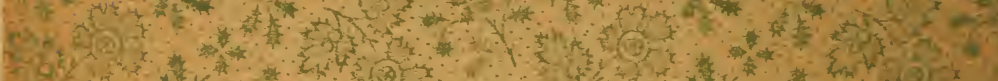

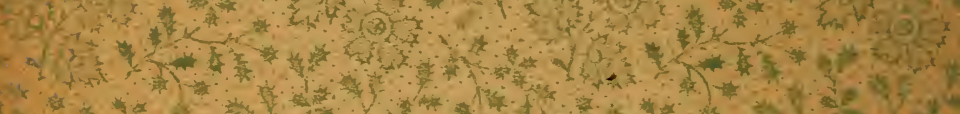

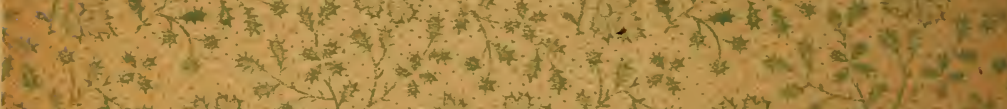

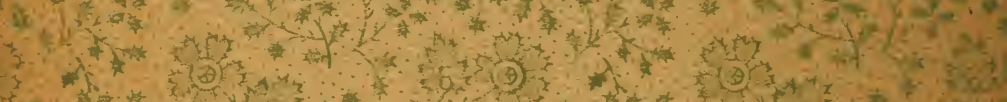

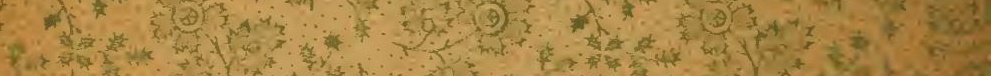

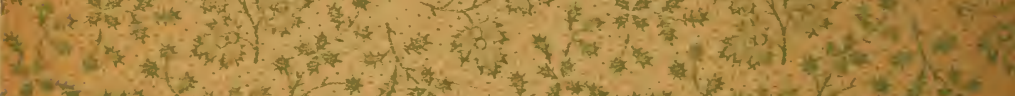

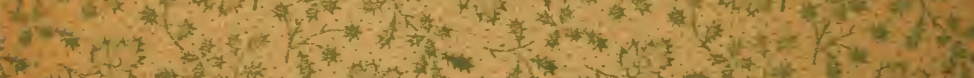
(2)

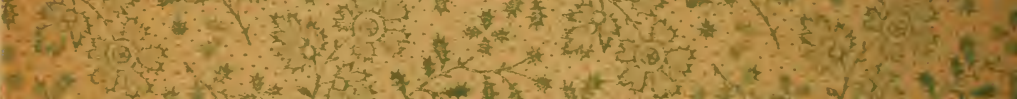

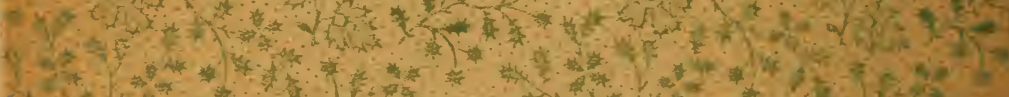

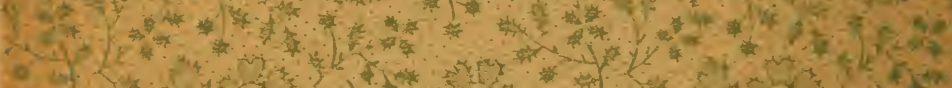

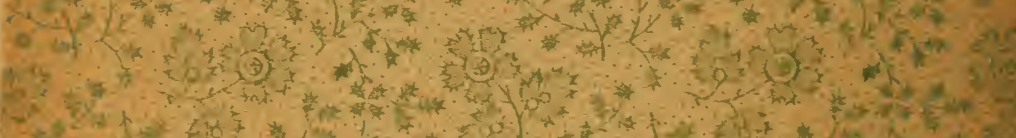

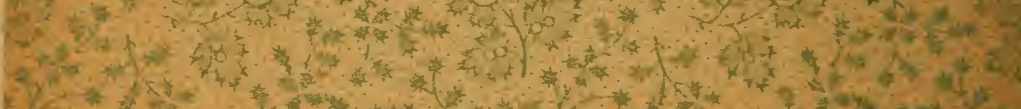

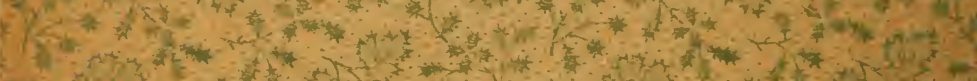

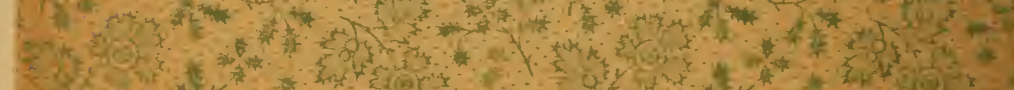

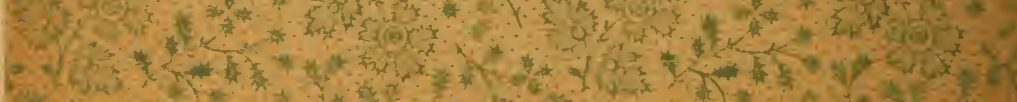

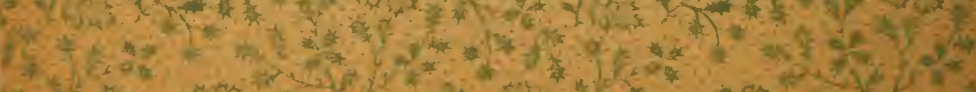

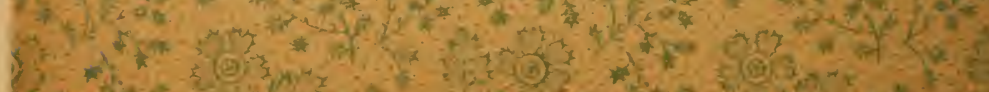
7.

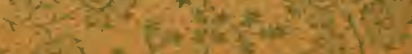




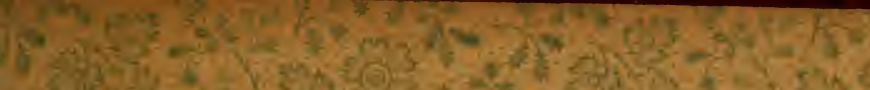

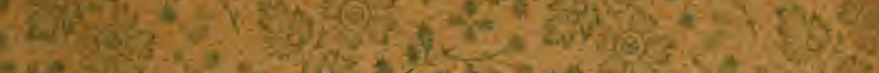

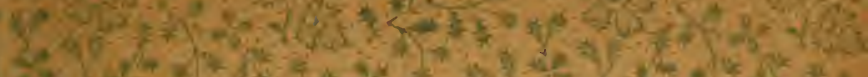
$x+x+2=2 x+2 x$ 1.2. 30.7

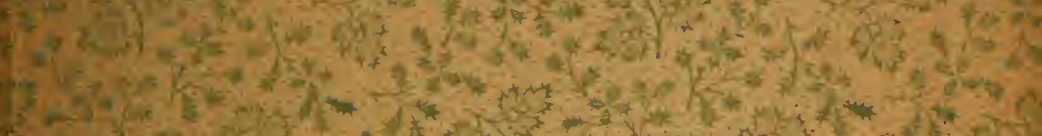

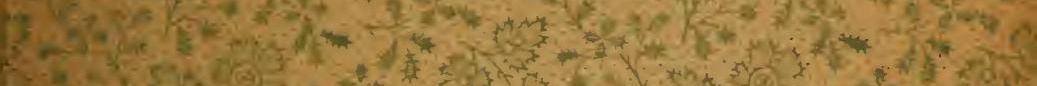

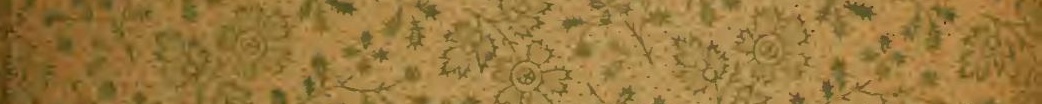

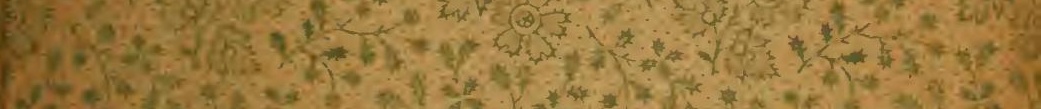

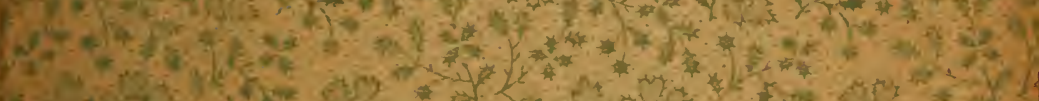

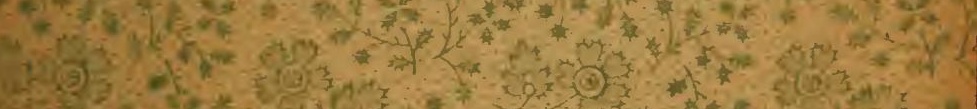

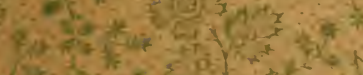

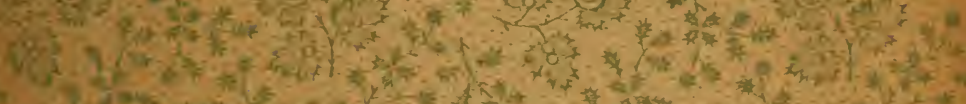

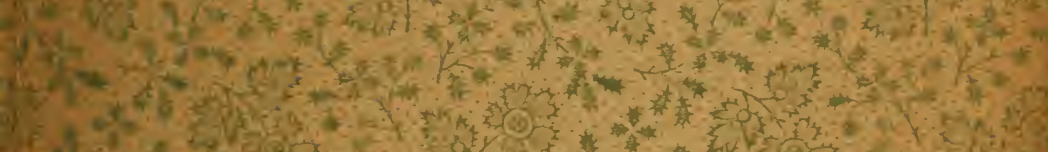

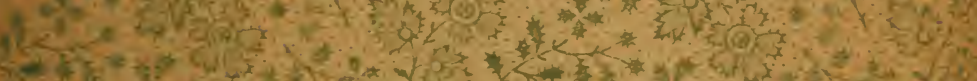

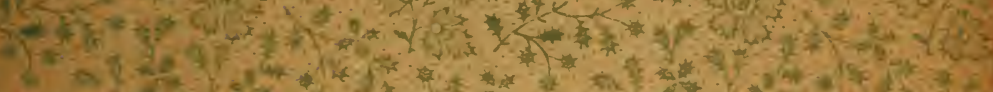

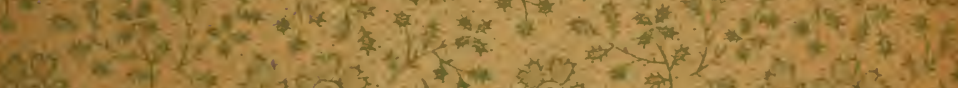

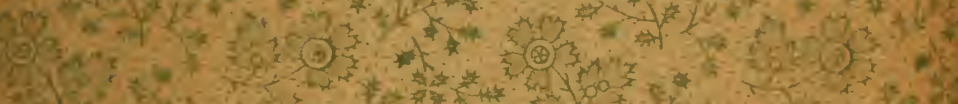
(15) S.6.

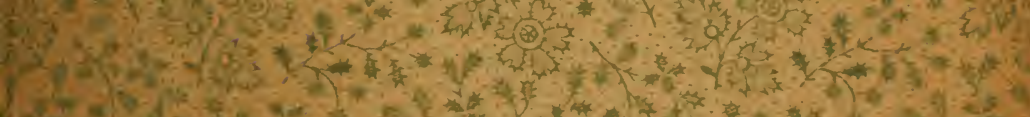

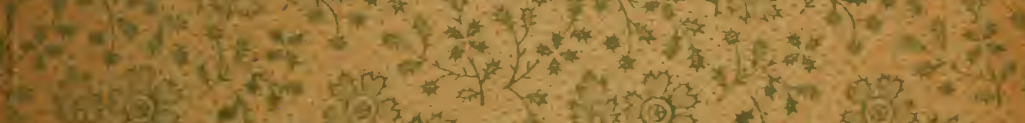
(e)

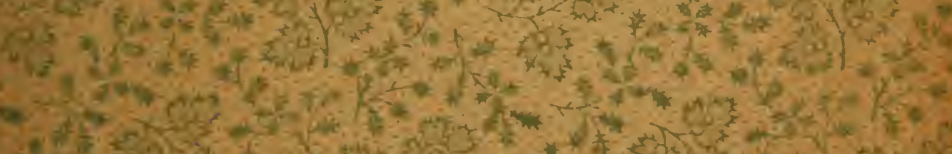

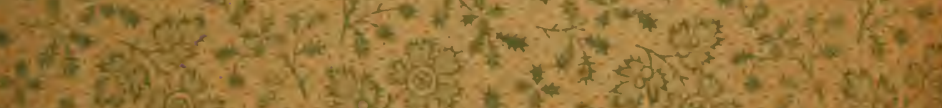
Whet

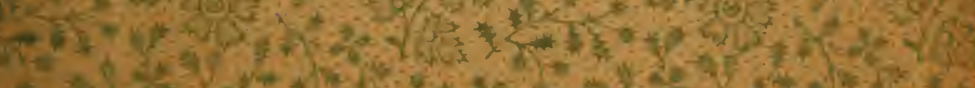

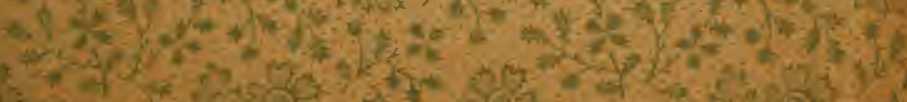

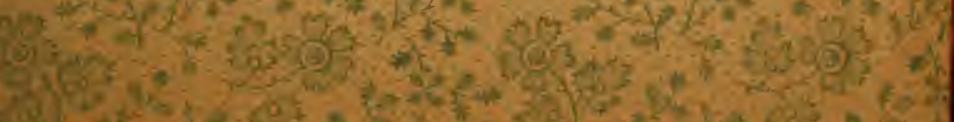
S1P. 
LIBRARY OF CONGRESS

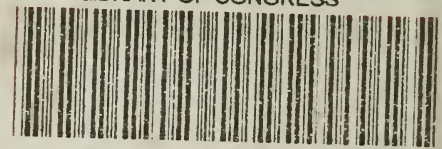

00053470890 